\title{
Decomposition in flocculent sediments of shallow freshwaters and its sensitivity to warming
}

\author{
Dustin W. Kincaid ${ }^{1,4}$, Nicolas A. H. Lara ${ }^{2,5}$, Scott D. Tiegs ${ }^{3,6}$, and Stephen K. Hamilton ${ }^{1,7}$ \\ ${ }^{1}$ W. K. Kellogg Biological Station and Department of Integrative Biology, Michigan State University, 3700 East Gull Lake Drive, \\ Hickory Corners, Michigan 49060 USA \\ ${ }^{2}$ Department of Biology, Oberlin College, 173 West Lorain Street, Oberlin, Ohio 44074 USA \\ ${ }^{3}$ Department of Biological Sciences, Oakland University, 318 Meadow Brook Road, Rochester, Michigan 48309 USA
}

\begin{abstract}
Shallow waterbodies are abundant in many landscapes across the globe and are increasingly acknowledged for their role in freshwater $\mathrm{C}$ cycling. This study investigated organic-matter decomposition potentials in flocculent organic sediment, a rarely-investigated sediment type commonly found in shallow waters. Further, this study investigated how porewater chemistry and temperature affect decomposition rates within flocculent sediment. We quantified decomposition rates during 3 seasons by deploying a standardized substrate (cotton strips) within and above the flocculent sediment layer in the littoral zones of lakes, shallow through-flow wetlands, and depositional zones on the margins of stream channels of southwestern Michigan, USA. We then compared our results with those reported for other freshwater settings that used the same cotton-strip assay. There was high accumulation of organic matter in the shallow waterbodies, but decomposition rates in flocculent sediments averaged $1.7 \times$ greater than rates measured in oxic overlying waters and were generally only eclipsed by temperatureadjusted rates reported in streams, which are typically well-oxygenated, flowing environments. Rates were positively correlated with sediment porewater concentrations of soluble reactive P and dissolved iron and negatively correlated with ammonium. Warmer temperatures also resulted in increased decomposition rates, and the temperature sensitivity results suggest that decomposition rates in flocculent sediments could increase 11 to $52 \%$ with a 1 to $4^{\circ} \mathrm{C}$ increase in water temperatures, a realistic range of increase for this region in the next $100 \mathrm{y}$ if climate change continues at the current pace. Thus, high organic matter inputs, rather than slow decomposition, must lead to the development of flocculent organic sediments. Future warming could therefore increase decomposition rates and tip the balance toward net losses of organic matter.
\end{abstract}

Key words: decomposition, organic matter, sediment, flocculent sediment, freshwater, cotton-strip assay, temperature sensitivity

Analyses of global $\mathrm{C}$ budgets show that freshwaters store significant amounts of organic $\mathrm{C}$ in their sediments (Cole et al. 2007, Battin et al. 2009, Tranvik et al. 2009). The greatest areal rates of organic $C$ burial tend to occur in small lakes, reservoirs, and ponds (Kortelainen et al. 2004, Downing et al. 2008, Brainard and Fairchild 2012, Ferland et al. 2012). In these systems, allochthonous and autochthonous $\mathrm{C}$ inputs are high, settling times in oxygenated water columns are short, and sediment resuspension is limited or only occurs episodically, especially in wind-protected waterbodies (Ferland et al. 2012, 2014). Consequently, sediment processes play a large role in determining the fate of organic $\mathrm{C}$ (i.e., burial vs mineralization) in freshwaters. However, our understanding of sediment $\mathrm{C}$ processing remains incomplete in freshwater systems (Burdige 2007, Sobek et al. 2011), especially in shallow waterbodies (Downing 2010).

Decomposition in sediments is regulated by several interacting factors including the physicochemical environment (particularly temperature and the availability of terminal electron acceptors including oxygen, nitrate, manganese, iron, and sulfate), the quantity and quality of $\mathrm{C}$, and the activity of microbes and detritivorous invertebrates (Fenchel et al. 2012). In fine sediments, including organic sediments, oxygen often becomes depleted within the first few $\mathrm{mm}$ of the sediment layer, whereas it becomes depleted within several cm in sandy sediments (Glud 2008, Sobek et al. 2009).

E-mail addresses: ${ }^{4}$ dustinkincaid@gmail.com; ${ }^{5}$ nlara@oberlin.edu; ${ }^{6}$ tiegs@oakland.edu; ${ }^{7}$ hamilton@msu.edu

DOI: 10.1086/706184. Received 15 March 2019; Accepted 12 June 2019; Published online 1 October 2019.

Freshwater Science. 2019. 38(4):899-916. ๑ 2019 by The Society for Freshwater Science. 
Thus, decomposition beneath the surface of organic sediments likely occurs anaerobically, potentially reducing rates relative to more oxygenated environments. Also, anoxic sediment porewaters tend to accumulate inorganic nutrients (e.g., ammonium and P; Wetzel 2001) and potentially toxic substances (e.g., ammonia, dissolved sulfide, or iron; Kinsman-Costello et al. 2015), though their effect on decomposition depends on conditions that vary among sediments. For example, in the absence of $\mathrm{C}$ limitation, decomposition is often constrained by the relative availability of $\mathrm{N}$ and $\mathrm{P}$ (i.e., N:P ratio) in organic matter and the environment (Güsewell and Gessner 2009), which depends on production, removal, and sorption processes within sediments that are different for $\mathrm{N}$ compared to P. Further, very high concentrations of sulfide or ammonium can inhibit the activity of decomposers, but levels of inhibition depend on factors that include environmental conditions (temperature and $\mathrm{pH}$ ) and the assemblage of decomposers (Chen et al. 2008).

Light availability above the sediments in shallow freshwaters may modulate these key factors and thereby also influence decomposition rates. For example, shallow-water sediments tend to receive more light and experience greater temperatures and temperature fluctuations than sediments in deeper waters. Solar radiation can directly influence decomposition of sediment organic matter beneath shallow water columns through photo-dissolution of dissolved and particulate fractions (Kieber et al. 2006, Mayer et al. 2006, 2009, Pisani et al. 2011, Shank et al. 2011). Light availability also indirectly affects decomposition by promoting the growth of algae and Cyanobacteria in the upper layers of the sediment. These communities, together with non-benthic photosynthetic organisms (e.g., submerged aquatic vegetation), influence decomposition by generating diel oscillations of oxygen and dissolved inorganic $\mathrm{C}$ concentrations via photosynthesis and respiration, affecting redox potential and $\mathrm{pH}$ in the sediment (Revsbech et al. 1988, Fenchel et al. 2012). Further, these organisms release organic exudates, stimulating microbial catabolism and nutrient mineralization (Wetzel 2001, Fenchel et al. 2012, Kuehn et al. 2014, Rier et al. 2014).

Warmer temperatures also increase metabolic activity, which often results in greater rates of sediment decomposition in shallow waters relative to sediments in deeper waters (Flanagan and McCauley 2010, Gudasz et al. 2010, 2015, Song et al. 2013). Climate change is projected to increase water temperatures throughout the year. This increase has uncertain implications for the balance between organic matter production and decomposition in freshwaters, which may also be affected by climate-driven changes in hydrology as well as detrital sources and inputs (Tranvik et al. 2009).

In shallow waterbodies that are continuously inundated, flocculent (floc) sediments often occur as thick layers. These sediments are loosely-consolidated organic deposits with dry bulk densities frequently $<0.1 \mathrm{~g} / \mathrm{cm}^{3}$ and water contents frequently $>90 \%$ (Kincaid 2018). In a recent survey of shallow lakes, wetlands, and the margins of streams in southwestern Michigan, floc accumulations ranged from 0.01 to $>2 \mathrm{~m}$ in thickness and were found in a wide variety of semito permanently-inundated habitats (Kincaid 2018). These habitats had productive aquatic vegetation, riparian vegetation, or both, as well as little current or wave action (Kincaid 2018). These habitats included, but were not limited to, the littoral zones of lakes, small reservoirs, persistentlyinundated wetlands, stream outlets in lakes, depositional zones in flowing systems, and groundwater seeps.

Little is known about the influence of floc sediments on ecosystem processes, including decomposition and nutrient cycling (but see Sweerts et al. 1986, Newman et al. 2001, Noe et al. 2003, Sommer 2006, Inglett et al. 2011, Pisani et al. 2011, 2015, Reddy et al. 2011, Longhi et al. 2013), even though floc is common (e.g., Sweerts et al. 1986, Bruland et al. 2006, Sommer 2006, Rivero et al. 2007, Longhi et al. 2013). In this study, we address this knowledge gap by measuring decomposition rates and their controls with a standardized cotton-strip assay (Tiegs et al. 2013a). This method allowed us to quantify decomposition potential, or the inherent capacity of floc accumulations to process organic matter, during 3 seasons in southwestern Michigan.

More specifically, we $1^{\text {st }}$ ask: what are decomposition rates of floc accumulations in shallow waters in southwestern Michigan? How do these rates compare to those in overlying water in these systems and to those in other freshwater ecosystems and habitats measured with the same cottonstrip assay we use here (Griffiths and Tiegs 2016, Wensink and Tiegs 2016, Vizza et al. 2017, Hervé et al. 2019, Tiegs et al. 2019)? We assumed that floc accumulations in our study are persistently anoxic because they consistently contain reduced iron or hydrogen sulfide and consistently lack nitrate (Kincaid 2018). Thus, we predicted that decomposition rates in floc would be slower than those rates measured in more oxic conditions. If this prediction is true, it would suggest that $\mathrm{C}$ turnover times are long in floc accumulations, which might partially explain why these thick layers accumulate over time.

Second, we explore how environmental variables within floc, specifically porewater chemistry and temperature, affect organic-matter decomposition rates. Which porewater chemistry variables are the best predictors of decomposition rates? How do decomposition rates vary with temperature? To do this, we measured decomposition rates within floc accumulations across naturally-occurring gradients in porewater chemistry. Again, we used the cotton-strip assay, which allowed us to control for organic $\mathrm{C}$ quality and assess the effect of site differences on decomposition rates (Harrison et al. 1988).

Lastly, to understand how decomposition rates in floc will respond to rising water temperatures projected as a result of climate change, we asked: how sensitive to temperature 
is this process? How does this value compare to those predicted by metabolic theory and reported in the literature in other freshwater environments? Addressing these questions contributes to understanding $\mathrm{C}$ cycling in an abundant but little-studied freshwater habitat.

\section{METHODS}

\section{Site selection}

We measured decomposition rates in thick floc accumulations $(>10 \mathrm{~cm})$ and in the water just above the sediment surface in a variety of shallow $(<1 \mathrm{~m})$ freshwater ecosystems (Table 1). The floc accumulations we chose are in diverse habitats, and the sources and forms of organic material in these accumulations probably vary among these sites. All sites were located in Kalamazoo County, Michigan, USA. Sites ranged from the littoral zones of lakes, shallow through-flow wetlands, and depositional zones along stream channel margins. These sites remain inundated in most or all years, often because they receive groundwater discharge. Most sites were devoid of vegetation, but a few sites had stands of emergent vegetation (e.g., Nuphar advena, Nymphaea odorata, Brasenia schreberi) or were among low densities of mixed assemblages of submerged aquatic vegetation (e.g., Ceratophyllum demersum, Chara spp., Myriophyllum spp., Potamogeton spp.).

\section{Cotton-strip decomposition assays}

We measured decomposition rates by deploying vertical arrays of cotton strips (Fig. 1) during 3 seasons in 2016: late spring (2-22 June), mid-summer (26 July-5 August), and autumn (6-20 October). The cotton-strip approach is a useful and standardized way to evaluate the overall decomposition potential of an ecosystem (Imberger et al. 2010). These strips have low nutrient content and are $~ 95 \%$ cellulose, which is the main detrital polymer in terrestrial ecosystems. Cellulose is part of the complex material lignocellulose that makes up the majority of organic $\mathrm{C}$ deposited in freshwater habitats (Megonigal et al. 2004). The use of standardized cotton strips for this assay, as opposed to plant material collected from our study sites with potentially variable organic matter composition, allowed us to control for organic $\mathrm{C}$ quality of the incubated material and assess the effect of site differences on decomposition rates (Harrison et al. 1988). Further, the cotton-strip assay has been employed in a variety of freshwater ecosystems and habitats, which allowed us to compare our measured rates to those in other settings (e.g., Tiegs et al. 2013a, Costello and Burton 2014, Griffiths and Tiegs 2016, Wensink and Tiegs 2016, Vizza et al. 2017, Hervé et al. 2019, Tiegs et al. 2019).

We standardized the individual cotton strips following the Tiegs et al. protocol (2013a). Briefly, we cut cotton strips $(8 \times 2 \mathrm{~cm})$ from bolts of unprimed $406 \mathrm{~g} / \mathrm{m}^{2}$ heavy-weight cotton canvas fabric (Style \#548, Fredrix, Lawrenceville, Georgia, USA), and ensured that each strip was 27 threads wide. We then created arrays of cotton strips by attaching 7 strips across galvanized steel frames with thin cable binders $(2.3 \mathrm{~mm}$ in width; Fig. $1 \mathrm{~A})$. At each site, we slowly inserted 2 replicate arrays into the floc so that the cotton strips were parallel to the floc-water interface. We left the top cotton strip above the floc but submerged in the overlying water (Fig. 1B). During June and October, the location of the floc-water interface relative to the cotton-strip array did not shift substantially during the deployment. We determined this with periodic visual inspections and the lack of discoloration on the upper cotton strip during the June and October deployments. During August, however, the upper cotton strips at some sites were buried in floc by an intense storm event. At those sites, all strips were located in the floc so we adjusted the array depths so the bottom strip was $18.4 \mathrm{~cm}$ below the floc-water interface.

The cotton-strip assay is thought to best approximate average in situ decomposition rates at tensile-strength losses (TSLs; explained below) of 50\% (Harrison et al. 1988, Tiegs et al. 2013a), so we removed strips after a duration that we estimated was sufficient to result in a median of $~ 50 \%$ TSL across all sites and depths each season. All cotton strips were removed at the same time so duration of incubation was identical. At the end of each deployment we carefully removed the arrays from the floc, rinsed them gently with deionized water, and soaked them in $80 \%$ ethanol for $\sim 30 \mathrm{~s}$ to arrest microbial activity and facilitate drying. After disassembling the arrays, we dried the cotton strips at $40^{\circ} \mathrm{C}$ for $24 \mathrm{~h}$.

\section{TSL determination}

We estimated decomposition rates as the TSL (Tiegs et al. 2013a). We measured the tensile strength of each deployed cotton strip with a tensiometer (Mark-10 MG100 Series, Copiague, New York, USA) after retrieving them from the field. The tensiometer pulled each strip at a fixed rate of $2 \mathrm{~cm} / \mathrm{min}$ until a maximum tensile strength value was reached and the strip tore. We determined initial tensile strength on a set of control strips that had not been deployed in the field but were rinsed and dried like the strips that had been deployed. There is little or no resistance met when inserting or retrieving cotton strips into loosely consolidated floc accumulations, so we did not insert and immediately retrieve control strips to account for stress on the strips resulting from insertion and retrieval, as is sometimes done. We expressed TSL of the deployed strips as \% of the initial tensile strength of control strips lost/d of deployment (TSL/day, hereafter non-adjusted TSL rates) as recommended by Tiegs et al. (2013a). The cube root method is an alternative method to linearize TSL that has historically been used in soil decomposition studies (Hill et al. 1985). We compared the results of both methods to assess the sensitivity of our inferences to the linear vs cube root method. This comparison showed that the 2 approaches 


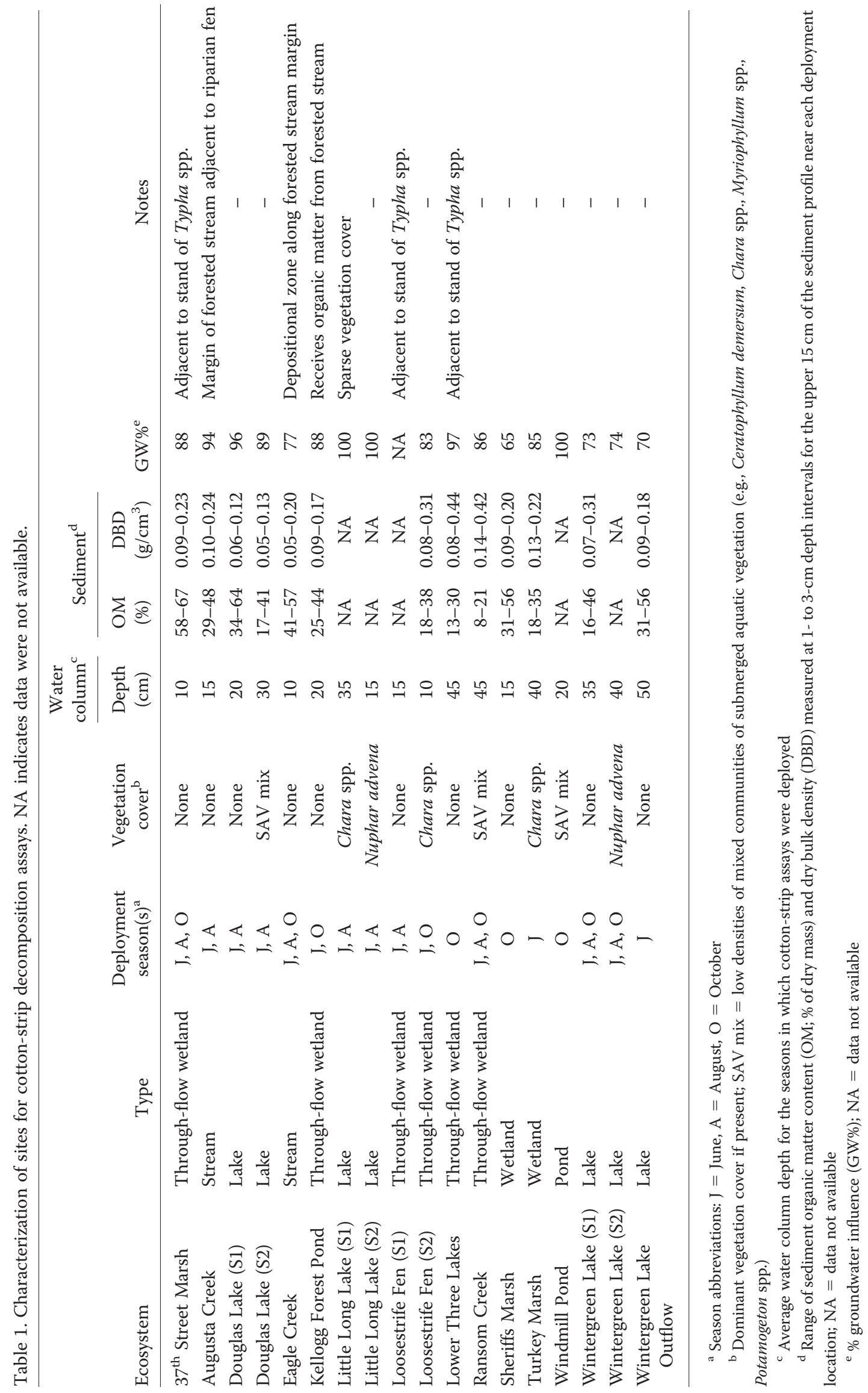

This content downloaded from 132.234.242.001 on March 31, 2020 15:59:13 PM 


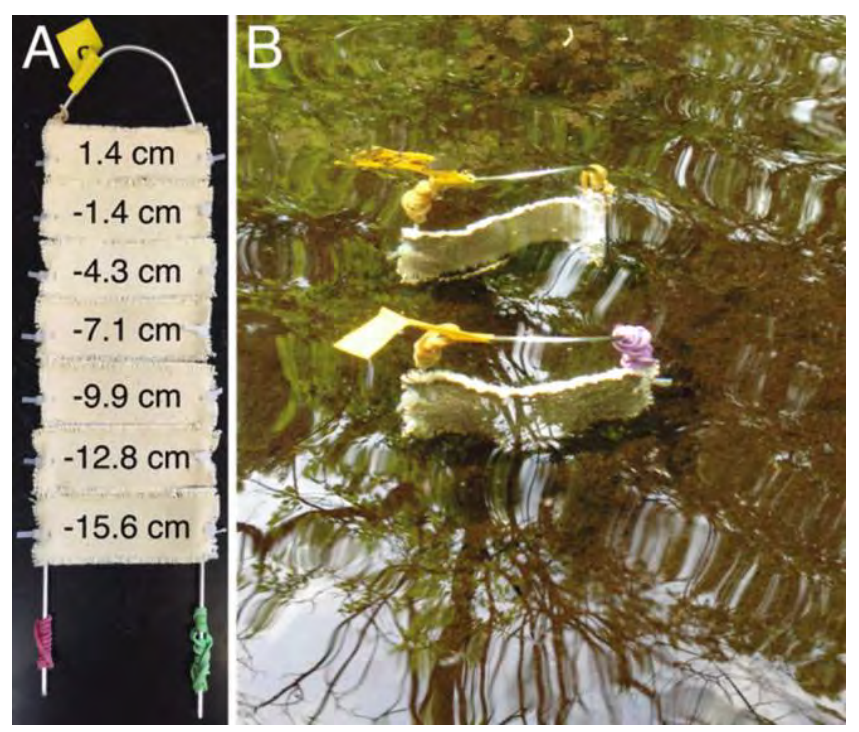

Figure 1. Illustration of a cotton strip array in the lab. Numbers are depths relative to the floc-water interface when deployed in the field (A). Two replicate arrays deployed in the field (B).

produced similar results, suggesting our inferences and interpretation of the results would be the same regardless of linearization method.

We expected temperature to strongly influence TSL rates. To evaluate differences in TSL that were not from temperature, we also calculated temperature-adjusted loss rates (/degree d; TSL/degday, hereafter temperature-adjusted TSL rates) by replacing time (d) with cumulative daily mean temperature (i.e., degree d; Woodward et al. 2012, Tiegs et al. 2013a, Griffiths and Tiegs 2016).

\section{Temperature measurements and water chemistry}

During each deployment we measured water temperature within and above the floc over time with Thermocron iButton ${ }^{\circledR}$ temperature loggers $(1912 \mathrm{H}$ and 1922L, Maxim Integrated, San Jose, California). These iButtons recorded water temperatures hourly at $2 \mathrm{~cm}$ above and 2 and $15 \mathrm{~cm}$ below the floc-water interface. We calculated daily temperature means at each of these depths. For strips located at depths without thermal loggers (i.e., 4.3, 7.1, 9.9, and $12.8 \mathrm{~cm}$ below the floc-water interface), we estimated daily mean temperatures by linearly interpolating daily means between the 2 and $15 \mathrm{~cm}$ depths below the floc-water interface.

We also sampled overlying water and floc porewater for chemical analysis at each site once during each deployment, though in August we only sampled the floc porewater. To sample the overlying water, we collected $\sim 250 \mathrm{~mL}$ of water in a clean bottle and stored it on ice until return to the laboratory. In the laboratory we filtered the samples through $0.45-\mu \mathrm{m}$ pore-size Supor polyethersulfone membrane filters (Pall Corporation, Port Washington, New York). To sample porewater in the upper $10 \mathrm{~cm}$ of floc, we carefully inserted a $10-\mathrm{cm}$-long Rhizon sampler $(0.15-\mu \mathrm{m}$ mean pore size; Rhizosphere Research Products, Wageningen, The Netherlands) vertically into the floc and slowly extracted $20 \mathrm{~mL}$ of porewater with a spring-loaded $30-\mathrm{mL}$ syringe connected to the Rhizon via Tygon ${ }^{\circledR}$ PVC tubing. We added subsamples of the filtered porewater into reagents in the field to produce stable colorimetric complexes with dissolved $\mathrm{Fe}^{2+}$ and $\Sigma \mathrm{H}_{2} \mathrm{~S}$. The remaining filtered portion stayed cold on ice until return to the laboratory. We stored all filtered samples at $4^{\circ} \mathrm{C}$ until analysis within $5 \mathrm{~d}$ of sample collection. Dissolved $\mathrm{O}_{2}$ was not measured in the floc because of methodological limitations; $\mathrm{O}_{2}$ depletion was indicated by the presence of dissolved $\mathrm{Fe}^{2+}$ and $\Sigma \mathrm{H}_{2} \mathrm{~S}$ in porewaters.

We measured concentrations of major ions (anions: $\mathrm{Br}^{-}$, $\mathrm{Cl}^{-}, \mathrm{NO}_{3}{ }^{-}$; cations: $\mathrm{Ca}^{2+}, \mathrm{K}^{+}, \mathrm{Mg}^{2+}, \mathrm{Na}^{+}$, and $\mathrm{NH}_{4}{ }^{+}$) with membrane-suppression ion chromatography (anions: Dionex ICS-1000; cations: Dionex ICS-1100). Analysis of $\mathrm{NH}_{4}{ }^{+}$ differed for overlying water and porewater samples: we determined $\mathrm{NH}_{4}{ }^{+}$concentrations in porewater samples with ion chromatography and in overlying water with the phenylhypochlorite colorimetric technique (Shimadzu UV-1700 spectrophotometer, Kyoto, Kyoto Prefecture, Japan; Aminot et al. 1997). We measured soluble reactive phosphorus (SRP) concentration colorimetrically (Shimadzu UV-1700 spectrophotometer) with the molybdate blue method and longpath-length spectrophotometry (Murphy and Riley 1962). We measured dissolved organic C (DOC) with the nonpurgeable organic $C$ method on a $C$ analyzer (Shimadzu TOC-VCPH) equipped for high-temperature, Pt-catalyzed combustion, and measured the resultant $\mathrm{CO}_{2}$ with gas chromatography. We measured dissolved $\mathrm{Fe}^{2+}$ in porewaters colorimetrically (Shimadzu UV-1700 spectrophotometer) with a ferrozine reaction method modified from Lovley and Phillips (1987) and Stookey (1970). For this measurement, we added filtered porewater to a solution of $50 \mathrm{mM}$ 4-(2hydroxethyl)-1-piperazineethanesulfonic acid buffer containing ferrozine $(1 \mathrm{~g} / \mathrm{L})$. We measured dissolved $\mathrm{\Sigma H}_{2} \mathrm{~S}$ in filtered subsamples of porewaters with the methylene blue spectrophotometric method (Golterman and Clymo 1969).

\section{Fungal biomass}

We estimated fungal biomass on cotton strips because the initial decomposition of plant material entering lakes and wetlands is largely accomplished by fungal assemblages (Komínková et al. 2000, Kuehn et al. 2000, Kuehn 2016). We estimated fungal biomass as ergosterol content (Newell 1992, Gessner and Newell 2002) on field-deployed cotton strips from a subset of depths from all sites in October. After gently rinsing the cotton strips with deionized water, we collected 2 disc-shaped subsamples (1.1-cm diameter) from strips deployed at $1.4 \mathrm{~cm}$ above and $1.4,7.1$, and $15.6 \mathrm{~cm}$ below the floc-water interface. We placed both subsamples in $10 \mathrm{~mL}$ of HPLC-grade methanol and refrigerated them 
in the dark at $4^{\circ} \mathrm{C}$ until analysis. To extract ergosterol, we placed the subsamples together in $5 \mathrm{~mL}$ of methanol and incubated them in a $65^{\circ} \mathrm{C}$ water bath for $2 \mathrm{~h}$. We then saponified the samples by adding a solution of $4 \% \mathrm{KOH}$ in 95\% ethanol and heating them for an additional $30 \mathrm{~min}$. We added pentane to partition the ergosterol extracted from the cotton discs, after which we evaporated the sample until dry with $\mathrm{N}$ gas, and then dissolved the sample again in $0.5 \mathrm{~mL}$ of HPLC-grade methanol. We quantified ergosterol with Dionex high performance liquid chromatography (Gulis and Suberkropp 2006).

\section{Data analysis}

Estimating \% groundwater contribution We estimated \% groundwater influence (GW\%) from surface water magnesium $\left(\mathrm{Mg}^{2+}\right)$ concentrations with a simple mixing model that assumes precipitation and groundwater represent the only $\mathrm{Mg}^{2+}$ inputs and $\mathrm{Mg}^{2+}$ concentrations were $1.65 \mu \mathrm{M}$ (NADP and NTN 2011) for precipitation and $1029 \mu \mathrm{M}$ for groundwater (Kalamazoo County mean; Thobaben and Hamilton 2014).

Seasonal differences in daily mean temperatures and decomposition rates To test for seasonal differences in daily mean temperatures and TSL rates, we conducted nonparametric Kruskal-Wallis rank sum tests for TSL rates across all seasons, analyzing the data for overlying water and floc (all depths combined) independently. Following the rejection of the null hypothesis $(\alpha=0.05)$, we conducted pairwise comparisons of TSL rates between seasons with 2 -sided Conover-Iman tests $(\alpha=0.05 / 2)$. Again, these were done independently for TSL rates measured in the overlying water vs those measured in floc (all depths combined). To control the false discovery rate we adjusted $p$-values with the Benjamini-Hochberg procedure (Benjamini and Hochberg 1995).

Differences in and predictors of decomposition rates between overlying water and floc To test for differences in TSL rates between those measured in the overlying water and those measured at different floc depths across all sites for each season, we conducted a non-parametric Friedman rank sum test to evaluate differences in rates measured at any depth. This test treated each cotton strip in a single array as a repeated measure and, thus, is a more conservative approach than the traditional non-parametric KruskalWallis test. Following the rejection of a Friedman test ( $\alpha=$ 0.05 ) for a season, we compared TSL rates measured in the overlying water to each depth in the floc with Wilcoxon signed rank tests $(\alpha=0.05)$. To control the false discovery rate we adjusted $p$-values with the Benjamini-Hochberg procedure.

We then assessed the environmental variables that best explained relative differences in TSL rates measured in the water vs the average of those measured within floc (all depths combined) at each site. To do this we calculated a TSL ratio for each site:

$$
\text { TSL ratio }=\frac{\text { MeanTSL } L_{\text {water }}}{\text { MeanTSL } L_{\text {floc }}}
$$

Non-adjusted and temperature-adjusted TSL ratios correlated positively with the mean of TSL rates measured in the overlying water at each site (TSL/d: $r=0.83, p<0.001$; TSL/degday: $r=0.87, p<0.001$ ), but not with the mean of rates measured in floc at each site (TSL/d: $r=-0.06$, $p=0.75$; TSL/degday: $r=0.01, p=0.94)$. Thus, the differences in TSL ratios were largely driven by changes in the magnitude of TSL rates in the overlying water at each site. Given this result, we assessed the water chemistry variables that best predicted temperature-adjusted TSL ratios in June and October in the overlying water (we did not collect overlying water samples in August). To do this we fit a generalized least squares (GLS) model with temperature-adjusted TSL ratios as the response variable and season and concentrations of SRP, DOC, $\mathrm{NH}_{4}{ }^{+}, \mathrm{NO}_{3}{ }^{-}, \mathrm{SO}_{4}{ }^{2-}, \mathrm{Mg}^{2+}, \mathrm{Ca}^{2+}$, and $\mathrm{Cl}^{-}$as covariates. We also fit a linear mixed-effects (LME) model that included site as a random effect to account for between-site variation and correlations between rates measured in the same site while still assessing the independent variables. However, including site as a random effect did not improve model fit ( $p=1.00$; Appendix S1, Table S5, Model M1 vs M2), so we use results from the more parsimonious GLS model. All continuous covariates had Pearson correlation coefficients $<0.7$, and we centered each of them at their means and scaled them by their standard deviations.

Differences in fungal biomass on cotton strips in October To test for differences in ergosterol concentrations on cotton strips in the overlying water vs those on cotton strips deployed at different floc depths, we used the same procedure as described previously for differences in decomposition rates (i.e., Friedman rank sum tests followed by Wilcoxon signed rank test followed by the BenjaminiHochberg procedure).

Predictors of decomposition rates in floc We assessed the floc porewater chemistry variables that best predicted temperature-adjusted TSL rates in floc with an LME model. The full model began with temperature-adjusted TSL rates as the response variable, season, depth, and concentrations of floc porewater solutes (SRP, $\mathrm{Fe}^{2+}, \mathrm{\Sigma H}_{2} \mathrm{~S}, \mathrm{DOC}, \mathrm{SO}_{4}{ }^{2-}$, $\mathrm{NH}_{4}{ }^{+}$, and $\mathrm{Ca}^{2+}$ ) as covariates and site as a random effect. The inclusion of site as a random effect allowed us to account for between-site variation and correlations between rates measured in the same site while assessing the independent variables. The LME model fit the data better than the GLS model ( $p<0.001$; Appendix S1, Table S7, Model M1 vs M2). The cotton-strip assay is thought to best approximate 
average in situ decomposition rates at TSLs of 50\% (Harrison et al. 1988), so we limited the dataset to cotton strips in floc with 25 to $75 \%$ TSL. We also excluded rates measured at $18.4 \mathrm{~cm}$ below the floc-water interface because these were few and only occurred in August. These filters removed 36\% of the 444 TSL measurements, but $>75$ measurements remained for each season (Appendix S1, Table S1). We did not include floc porewater $\mathrm{NO}_{3}{ }^{-}$as a covariate in these models because most of our measurements were at or below the detection limit. All continuous covariates had correlations $<0.7$, and we centered each of them at their means and scaled them by their standard deviations.

Apparent temperature sensitivity of decomposition rates in the floc We assessed the apparent temperature sensitivity of TSL rates in floc sediments with the BoltzmannArrhenius function derived from metabolic theory (Brown et al. 2004). This function quantifies temperature sensitivity as activation energy $\left(E_{a}\right)$. The greater the value of the $E_{a}$, the more sensitive biological activity is to temperature. The decomposition of cellulose involves multiple organisms and many biochemical reactions, so the $E_{a}$ of this process actually represents an apparent (i.e., empirical) temperature sensitivity. To quantify $E_{a}$, we used the same BoltzmannArrhenius function recently used to estimate the temperature sensitivity of leaf litter breakdown in streams (Follstad Shah et al. 2017):

$$
\ln r=\ln r_{0}-E_{a} \times\left(1 / k_{\mathrm{B}} T-1 / k_{\mathrm{B}} T_{0}\right)
$$

where $r_{O}$ is a normalization constant, $E_{a}$ is the apparent activation energy $(\mathrm{eV}), k_{\mathrm{B}}$ is the Boltzmann constant $(8.62 \times$ $\left.10-5 \mathrm{eV} \mathrm{K}^{-1}\right), T$ is temperature in Kelvin $(\mathrm{K})$, and $T_{O}$ is a standard temperature. The final term $\left(1 / k_{\mathrm{B}} T-1 / k_{\mathrm{B}} T_{0}\right)$ in this equation is the inverse absolute temperature and is used to center the temperature data on a standard temperature (Allen et al. 2005, Yvon-Durocher et al. 2012). We used a standard temperature of $18^{\circ} \mathrm{C}(291.15 \mathrm{~K})$ because this was close to the median daily mean temperature in floc during the cotton-strip array deployments. In this equation, $r$ represents the non-adjusted TSL rates. We then obtained the value of $E_{a}$ from the slope of the relationship between the inverse absolute temperature and $\ln (r)$.

To estimate $E_{a}$ we used an LME model with non-adjusted TSL rates as the response variable, inverse normalized temperature $(\mathrm{eV})$ as a covariate, and site as a random effect. Once again, we limited the data to cotton strips with 25 to $75 \%$ TSL. The inclusion of site as a random effect allowed us to account for between-site variation and correlations between rates measured in the same site while assessing the independent variables. The MLE model fit the data better than the GLS model ( $p<0.001$; Appendix S1, Table S8, Model M1 vs M2). This particular random intercept model assumes that the variability in site characteristics influences non-adjusted TSL rates but not the temperature sensitivity of non-adjusted TSL rates. To test this assumption, we also fit a model with a random intercept (site) and slope (inverse normalized temperature).

Model building and statistical inference We conducted all statistical analyses in R v3.4.3 (R Project for Statistical Computing, Vienna, Austria) with RStudio v1.1.383. We fit GLS and LME models with the nlme package (Pinheiro et al. 2017). Model selection for both model types began with the inclusion of all fixed effects (Zuur et al. 2009). We then assessed whether the inclusion of the random site effect improved model fit with likelihood ratio tests. These comparisons included the full model (with all possible fixed effects) with and without the random term. We selected the most parsimonious model consisting of significant factors $(\alpha=0.05)$ by sequentially removing 1 fixed effect and comparing the new reduced model forms to more complex models with Akaike information criterion scores and likelihood ratio $(L)$ tests. When testing for the significance of random effects, we fit models with restricted estimated maximum likelihood. When comparing models with different fixed effects, we fit models with maximum likelihood. We refit the final, simplest model, with restricted estimated maximum likelihood to provide the best estimates of standard errors and random effects (Zuur et al. 2009).

We assessed models for linearity, normality, and homoscedasticity by plotting normalized residuals based on the restricted estimated maximum likelihood fit against fitted values and predictor variables. We also assessed goodness of fit with quantile-quantile plots. We report model parameters along with their standard errors.

\section{RESULTS}

\section{Water chemistry and temperature}

The major solute concentrations in surface waters at the study sites indicate strong groundwater influence. The contribution of groundwater to the study sites ranged from 65 to $100 \%$ groundwater, with a median of $88 \%$ (Table 1 ). The dominant ions were $\mathrm{HCO}_{3}{ }^{-}, \mathrm{Ca}^{2+}$, and $\mathrm{Mg}^{2+}$ (Appendix S1, Table S2).

DOC and nutrient chemistry varied greatly across sites and between overlying waters and the floc sediment (Table 2). The coefficients of variation for mean surface water DOC, $\mathrm{NH}_{4}{ }^{+}, \mathrm{NO}_{3}{ }^{-}$, and SRP concentrations across sites were 93, 77,172 , and $67 \%$, respectively. Floc typically accumulated DOC, $\mathrm{NH}_{4}{ }^{+}$, and SRP relative to overlying waters, with mean concentrations in floc exceeding concentrations in overlying water by factors ranging from $\sim 2$ to 10,15 to 912 , and 3 to 481, respectively. Conversely, floc $\mathrm{NO}_{3}{ }^{-}$concentrations were lower than overlying water concentrations at 12 of the 18 sites. Site- and season-specific chemistry data are included in Appendix S1 and Table S2.

Daily mean temperatures varied by season for both overlying water and floc $(p<0.001$; Appendix S1, Table S3, 
Table 2. Surface water and sediment porewater nutrient chemistry at cotton-strip decomposition assay sites. Values represent mean concentrations measured across all 3 seasons. Site- and season-specific chemistry is included in Appendix S1, Table S2. NA indicates data were not available.

\begin{tabular}{|c|c|c|c|c|c|c|c|c|}
\hline \multirow[b]{2}{*}{ Ecosystem } & \multicolumn{4}{|c|}{ Surface water } & \multicolumn{4}{|c|}{ Sediment porewater } \\
\hline & $\mathrm{DOC}(\mu \mathrm{M})$ & $\mathrm{NH}_{4}^{+}(\mu \mathrm{M})$ & $\mathrm{NO}_{3}^{-}(\mu \mathrm{M})$ & $\mathrm{SRP}(\mu \mathrm{M})$ & $\mathrm{DOC}(\mu \mathrm{M})$ & $\mathrm{NH}_{4}^{+}(\mu \mathrm{M})$ & $\mathrm{NO}_{3}^{-}(\mu \mathrm{M})$ & $\operatorname{SRP}(\mu \mathrm{M})$ \\
\hline $37^{\text {th }}$ Street Marsh & 0.34 & 3.68 & 8.36 & 0.19 & 3.26 & 434.80 & 0.33 & 17.04 \\
\hline Augusta Creek & 0.46 & 0.64 & 127.65 & 0.10 & 2.17 & 181.63 & 1.47 & 9.72 \\
\hline Douglas Lake (S1) & 0.25 & 0.79 & 0.21 & 0.14 & 1.85 & 67.36 & 0.39 & 3.42 \\
\hline Douglas Lake (S2) & 0.54 & 0.64 & 0.07 & 0.08 & 3.54 & 231.46 & 2.53 & 11.14 \\
\hline Eagle Creek & 0.35 & 3.32 & 4.40 & 0.12 & 2.15 & 55.09 & 3.21 & 4.64 \\
\hline Kellogg Forest Pond & 0.48 & 2.90 & 89.67 & 0.22 & 1.94 & 652.89 & 0.61 & 48.33 \\
\hline Little Long Lake (S1) & 0.86 & 1.86 & 2.64 & 0.11 & 1.35 & 1000.86 & 1.75 & 1.60 \\
\hline Little Long Lake (S2) & 0.36 & 2.93 & 93.52 & 0.19 & 1.76 & 170.63 & 0.29 & 1.74 \\
\hline Loosestrife Fen (S1) & NA & NA & NA & NA & 2.34 & 733.70 & 0.43 & 3.88 \\
\hline Loosestrife Fen (S2) & 0.67 & 0.64 & 0.07 & 0.09 & 2.34 & 313.34 & 0.07 & 9.79 \\
\hline Lower Three Lakes & 0.48 & 2.86 & 7.07 & 0.09 & 2.08 & 139.00 & 0.07 & 19.91 \\
\hline Ransom Creek & 0.45 & 0.54 & 0.25 & 0.11 & 1.79 & 321.05 & 1.26 & 15.13 \\
\hline Sheriffs Marsh & 3.22 & 0.64 & 0.07 & 0.45 & 6.66 & 583.42 & 0.07 & 18.22 \\
\hline Turkey Marsh & 1.17 & 0.29 & 0.29 & 0.32 & 1.94 & 21.56 & 0.07 & 1.03 \\
\hline Windmill Pond & 0.31 & 6.71 & 76.60 & 0.10 & 1.96 & 1195.83 & 0.86 & 48.11 \\
\hline Wintergreen Lake (S1) & 0.75 & 2.93 & 4.47 & 0.13 & 2.82 & 902.43 & 0.19 & 11.73 \\
\hline Wintergreen Lake (S2) & 0.95 & 2.68 & 3.40 & 0.16 & 2.56 & 575.64 & 0.50 & 27.49 \\
\hline Wintergreen Lake Outflow & 1.08 & 3.71 & 0.14 & 0.46 & 3.12 & 56.26 & 0.07 & 2.13 \\
\hline
\end{tabular}

Fig. 2A), with the warmest mean temperature occurring in August and the coldest in October. Daily mean temperatures differed between overlying water and floc in June and August but not October (June and August: $p<0.001$, October: $p=0.64$; Appendix S1, Table S3, Fig. 2A).

Temperature profiles varied by season (Fig. 3A). In June, the warmest daily mean temperatures occurred in the overlying water, whereas the coldest daily mean temperatures occurred at the maximum depth measured in floc. Temperatures in August generally decreased and became less varied with depth. In October, the temperature profile was more uniform with depth. Site- and season-specific temperature profiles are included in Appendix S2 and Fig. S1.

\section{Seasonal variation in decomposition rates}

There were seasonal differences in median TSL rates ( $p$ $<0.05$; Appendix S1, Table S3) that generally reflected patterns in seasonal temperatures (Fig. 2A-C). In August, median non-adjusted rates were $>4 \times$ and $2 \times$ higher than median rates in the coldest season (October) in the overlying water and floc, respectively (Fig. 2B). This pattern remained even when rates were adjusted for temperature (TSL/degday; Fig. 2C), though the magnitude of change between the seasons was not as large.

\section{Differences in decomposition rates between overlying water and floc}

Median non-adjusted TSL rates were generally greater in floc than in the overlying water for all seasons (Fig. 3B), and the difference was significant for all floc depths in June $\left(\chi_{(6)}^{2}=27.61, p<0.001\right)$ and October $\left(\chi_{(6)}^{2}=20.20, p=\right.$ $0.002)$, but not August $\left(\chi_{(6)}^{2}=6.56, p=0.36\right)$. This pattern remained after adjusting rates for temperature (June: $\chi_{(6)}^{2}=41.57, p<0.001$; August: $\chi_{(6)}^{2}=9.64, p=0.14$; October: $\chi_{(6)}^{2}=20.16, p=0.003$; Fig. 3C).

We also assessed the relative differences in TSL rates measured in the overlying water vs those measured in floc at each site (TSL ratio). For all seasons, TSLs in the overlying water were on average $60 \%$ (range $=<1-156 \% \mathrm{TSL} / \mathrm{d}$ ) and $57 \%$ (range $=<1-151 \%$ TSL/degday) of those in floc. For June and October only, average TSL ratios were 59\% TSL/d and 55\% TSL/degday. The most important water chemistry predictor of temperature-adjusted TSL ratios for June and October was the concentration of $\mathrm{Ca}^{2+}\left(\beta_{\mathrm{Ca}}=\right.$ $0.22 \pm 0.08, p=0.008)$, followed by the concentration of $\mathrm{Mg}^{2+}\left(\beta_{\mathrm{Mg}}=-0.14 \pm 0.08, p=0.08\right.$; Model M10 in Appendix S1, Table S5). Relative differences between mean temperature-adjusted TSL rates in the overlying water and floc decreased, or rather the temperature-adjusted TSL ratio 

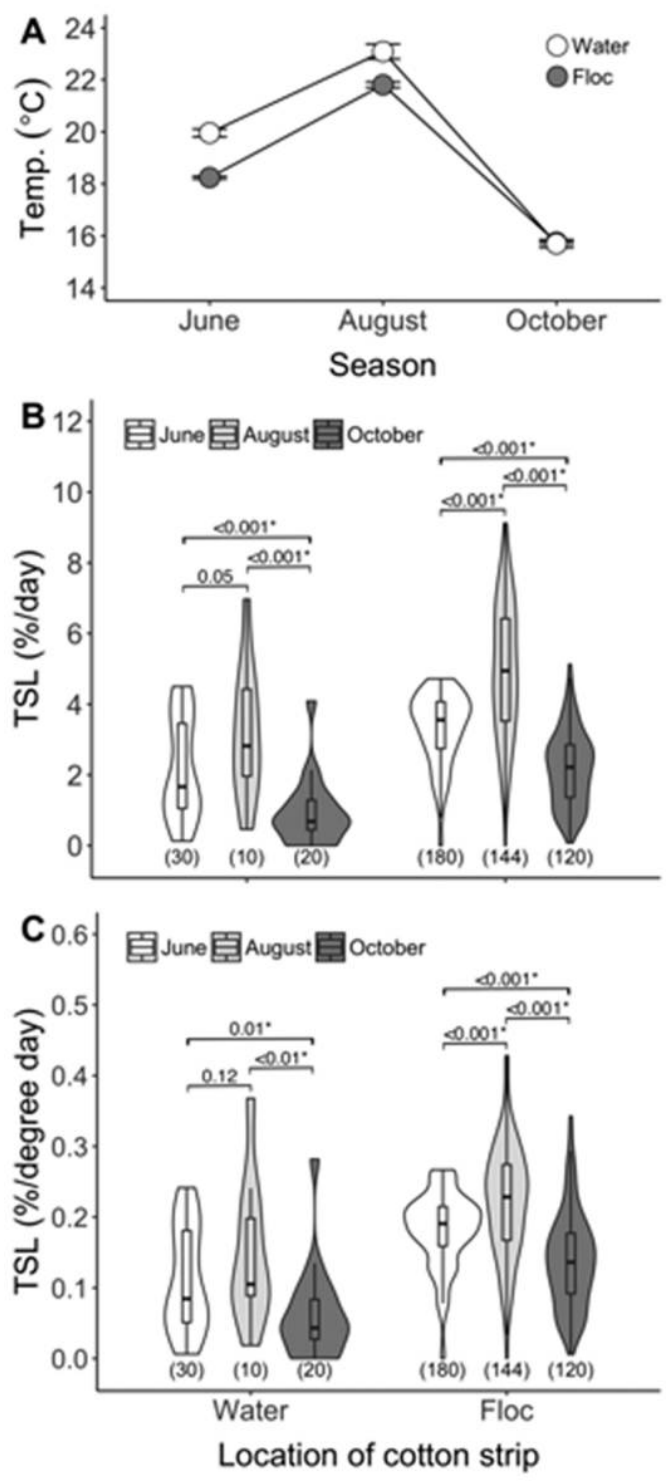

Figure 2. Daily mean temperatures (A), non-adjusted tensilestrength loss (TSL; B), and temperature-adjusted TSL (C) across all sites for cotton strips in the overlying water and floc. Data used in each plot are site means. Error bars in (A) represent \pm standard error of the mean. Violin plots in B and C show the density distribution of TSL rates. Boxplots within the violin plots represent the median and interquartile range. Values above brackets in $\mathrm{B}$ and $\mathrm{C}$ are $p$-values for pairwise comparisons; * indicates significant $p$-values (Appendix S1, Table S3). Values in parentheses in $\mathrm{B}$ and $\mathrm{C}$ are the number of measurements.

moved closer to 1 , as the concentration of $\mathrm{Ca}^{2+}$ in the surface water increased.

\section{Differences in fungal biomass on cotton strips in October}

Ergosterol concentrations, our proxy for fungal biomass, were close to the analytical detection limit on all cotton strips. Median concentrations across all sites in Octo- ber were greatest on cotton strips in the overlying water (Fig. 4), though they were only significantly greater than on cotton strips deployed at $-7.1 \mathrm{~cm}\left(\chi_{(3)}^{2}=14.64, p=\right.$ 0.002; Appendix S1, Table S6).

\section{Predictors of decomposition rates in floc}

Floc temperature had a strong positive effect on nonadjusted TSL rates, and when evaluated in isolation, temperature explained nearly $1 / 2$ of the variation in these rates (Fig. 5).

After adjusting TSL rates for temperature, there was still considerable variation in TSL across sites (Fig. 3C), so we assessed which floc porewater chemistry variables were the best predictors of temperature-adjusted TSL rates. SRP concentration was the best predictor of these rates $\left(\beta_{\mathrm{SRP}}=0.02 \pm 0.005, p<0.001\right)$, followed by the concentrations of $\mathrm{Fe}^{2+}\left(\beta_{\mathrm{Fe}}=0.01 \pm 0.004, p=0.02\right)$ and $\mathrm{NH}_{4}{ }^{+}\left(\beta_{\mathrm{NH} 4}=-0.01 \pm 0.005, p=0.01\right.$; Model M7 in Appendix S1, Table S7).

No single waterbody type considered in this study had consistently higher decomposition rates in any season (Fig. 6A). Similarly, there were no consistent patterns in dominant vegetation (Fig. 6B). However, our study design did not allow us to evaluate either of these variables robustly.

\section{Apparent temperature sensitivity of decomposition rates in floc}

The apparent activation energy $\left(E_{a}\right)$ of decomposition in the upper $\sim 16 \mathrm{~cm}$ of floc was $0.78 \pm 0.04 \mathrm{eV}$ (95\% CI: 0.70-0.86 eV; Fig. 7A, Model M2 in Appendix S1, Table S8). The depth-specific $E_{a}$ estimates were lowest at $1.4 \mathrm{~cm}$ below the floc-water interface and increased with depth (Fig. 7B).

\section{DISCUSSION}

\section{Decomposition rates in floc}

Contrary to our expectation, the decomposition rates we observed in floc were similar to those reported in more oxic freshwater environments such as streams. The TSL rates in floc we report here are on the upper end of the range of values reported for streams and riparian zones, which is where most studies that use the cotton-strip assay method have been conducted. In a global-scale field experiment in $>500$ streams that measured TSL rates on cotton strips deployed in streams and adjacent riparian zones, Tiegs et al. (2019) found mean non-adjusted TSL rates (TSL/d) of $3.27 \pm 0.15$ and $1.48 \pm 0.10 \%$ in streams and riparian zones, respectively. In this study, based on strips with TSL in the range of 25 to $75 \%$, the mean across all floc depths and seasons was $3.86 \pm 0.10 \%$ (Fig. $2 \mathrm{~B}$ ). When adjusted for exposure to different temperatures, the mean TSL rate (TSL/degday) in floc across all seasons $(0.20 \pm 0.004 \%$; Fig. 2 C) was less than that reported by Tiegs et al. (2019) for stream environments $(0.31 \pm 0.016 \%)$, but nearly equivalent to mean 

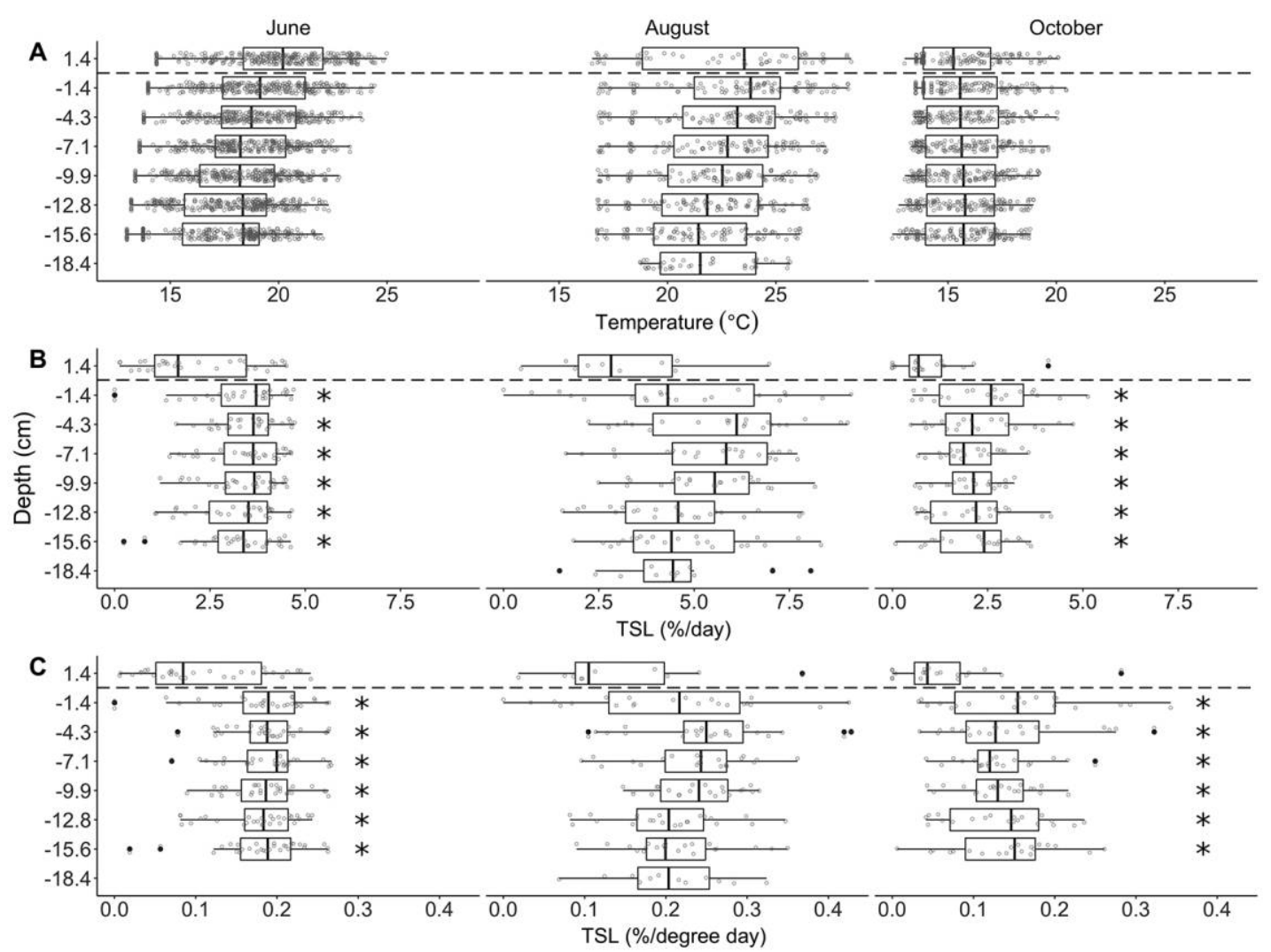

Figure 3. Daily mean temperatures (A), non-adjusted tensile-strength loss (TSL; B), and temperature-adjusted TSL (C) at each depth above $(1.4 \mathrm{~cm})$ and below $(-1.4$ to $-18.4 \mathrm{~cm})$ the floc-water interface (depicted as dashed horizontal line) for all sites. Each gray point represents a mean temperature for each day of the incubation in panel A and a TSL rate for a single cotton strip in panels B and $\mathrm{C}$. These points are jittered along the y-axis. Boxplots represent the median and interquartile range; outliers are depicted as black points. " indicates that rates at these depths are significantly different than those above the floc-water interface for that season according to post-hoc comparisons (Appendix S1, Table S4).

temperature-adjusted TSL rates that they measured in riparian zones $(0.17 \pm 0.015 \%)$. Thus, decomposition in floc occurred as quickly as it did in riparian environments and slightly more slowly than it did in all stream sites.

Non-adjusted TSL rates (TSL/d) in floc were also greater than those reported in non-stream environments. Mean non-adjusted TSL rates in floc were $\sim 2 \times$ greater than mean rates reported for nearshore habitats of a large temperate lake in Michigan, USA (1.9\%/d; Wensink and Tiegs 2016) and vernal pool sediments in France $(1.9 \% / d$; Hervé et al. 2019), and nearly $12 \times$ greater than the maximum mean rate reported for wetland ponds in Alaska, USA (0.3\%/d; Vizza et al. 2017). These latter studies did not report temperatureadjusted rates, so interpreting these comparisons is more difficult given likely differences in site temperatures, but the mean rate during our coldest season, October $(2.19 \pm$ $0.10 \%$, Fig. $2 \mathrm{~A}-\mathrm{C}$ ), was still greater than the rate observed in non-stream environments in these studies.

\section{Why are decomposition rates greater in floc than in overlying water?}

Contrary to our prediction, decomposition rates were consistently greater in floc than in the overlying water, even when rates were adjusted for temperature. Median TSL rates in the overlying water were significantly lower than median TSL rates measured in all depths in floc in June and October (Fig. 3A-C). Furthermore, the majority of sites $(>90 \%)$ had TSL ratios $<1$, demonstrating that the disparity between rates in the overlying water and floc is common and not the result of a few anomalous sites or differences in field deployment times. The absence of significant differences between TSL rates measured in the overlying water and those measured in floc in August (Fig. 3A-C) could be from a seasonal homogenization of TSL rates in the overlying water and floc, but is more likely an artifact of low replication because of burial of cotton strips in the overlying water by sediment disturbance after a large storm event. Regardless, decomposition occurred rapidly within floc relative to rates measured in overlying water.

Our prediction that decomposition rates would be greatly reduced in floc was based on the assumption that decomposition is restricted under anoxic conditions, as others have observed (Reddy and Patrick 1975, Godshalk and Wetzel 1978, DeBusk and Reddy 1998). However, several studies in marine sediments, where the effect of oxygen on organic-matter decomposition has received considerable 


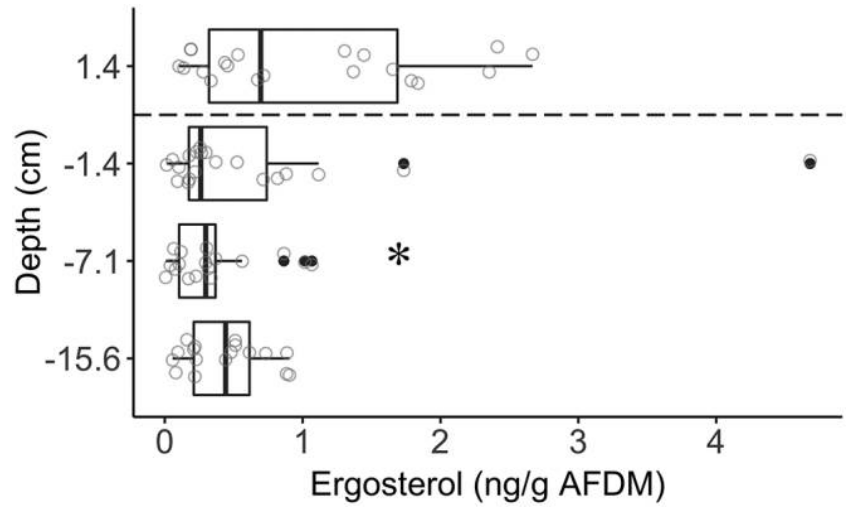

Figure 4. Fungal biomass estimated as ergosterol concentrations (ng/g ash-free dry mass [AFDM]) on cotton strips deployed above $(1.4 \mathrm{~cm})$ and below $(-1.4,-7.1$, and $-15.6 \mathrm{~cm})$ the floc-water interface (depicted by dashed horizontal line) for all sites in October. Each gray point represents a single cotton strip. These points are jittered along the $y$-axis. Box plots represent the median and interquartile range; outliers are depicted as black points. " indicates that concentrations at that depth are significantly different than those in the overlying water $(1.4 \mathrm{~cm})$ according to post-hoc comparisons (Appendix S1, Table S6).

attention (Burdige 2007), have revealed that the relation between oxygen availability and the degradation of particulate organic matter depends on the nature of the substrate. Essentially, fresh, less-refractory organic matter is degraded at similar rates regardless of whether oxygen is present, whereas aged, more-refractory organic matter is degraded at greatly-reduced rates under anoxic conditions (Kristensen et al. 1995, Hulthe et al. 1998, Kristensen and Holmer 2001). The high in-floc decomposition rates we observed in this study could be because cellulose, the main constituent of cotton strips, is an easily-degraded biopolymer (Pérez et al. 2002). Alternatively, studies have demonstrated that exposure to oscillating redox conditions can stimulate overall mineralization of organic matter (Reddy and Patrick 1975, Aller 1994, Aller et al. 1996, Hulthe et al. 1998). We did not measure redox potential while the cotton strips were deployed, but we previously observed redox oscillations in floc that are potentially associated with diurnal photosynthetic activity, bioturbation, and introduction of oxidants (e.g., oxygen and $\mathrm{NO}_{3}{ }^{-}$) into floc following convective mixing events with overlying water, or some combination of these factors (Kincaid 2018). However, the enhanced decomposition rates in floc compared to the overlying water suggests factors in addition to oxygen availability result in greater rates of decomposition in floc sediments.

Degradation of cellulose requires the production of extracellular enzymes by bacterial and fungal assemblages (Leschine 1995, Lynd et al. 2002). Thus, greater TSL rates in floc relative to overlying water might result partially from a greater abundance of microorganisms in floc, which would aid in rapid colonization and decomposition of cotton strips. Fungi are critically important decomposers of biopolymers in soils (de Boer et al. 2005) and stream eco- systems (Kuehn 2016), so we estimated fungal biomass on cotton strips after retrieving them from the field. We found that biomass was low overall on the cotton strips but tended to be greater on cotton strips deployed in the water overlying floc than on those deployed in floc (Fig. 4). This result could be from oxygen limitation, as many fungi are considered obligate aerobes, although some can survive and remain active under anoxic conditions, including in lake sediments (Wurzbacher et al. 2010). Further, fungal biomass is often positively correlated with the size of particulate organic matter in which the fungi dwell (Sinsabaugh et al. 2002), so the low biomass of fungi on cotton strips could be because of the small size of average floc aggregates. Regardless, fungal biomass did not explain the greater decomposition rates in floc compared to overlying water.

Factors that potentially influence decomposition rates in floc at our study sites, including bacterial abundance, algal communities, and the role of $\mathrm{Ca}^{2+}$ in preventing extracellular enzyme inactivation by dissolved organic compounds were not measured in this study. Bacteria can play significant roles in degrading organic C (Benner et al. 1986, Tanaka 1991), and they are typically far more abundant in sediments than in an equivalent volume of overlying water (Wetzel 2001, Fenchel et al. 2012). Algal communities can indirectly enhance decomposition rates in sediments underlying shallow water columns by altering the dissolved $\mathrm{O}_{2}, \mathrm{pH}$, and redox potential (Revsbech et al. 1988, Fenchel et al. 2012) and by releasing organic exudates that stimulate microbial activity (Wetzel 2001, Fenchel et al. 2012, Rier et al. 2014, Kuehn et al. 2014). We consistently observed algal pigments (i.e., chlorophyll $a$ ) at varying concentrations up to $\sim 30 \mathrm{~cm}$ below the floc-water interface in similar

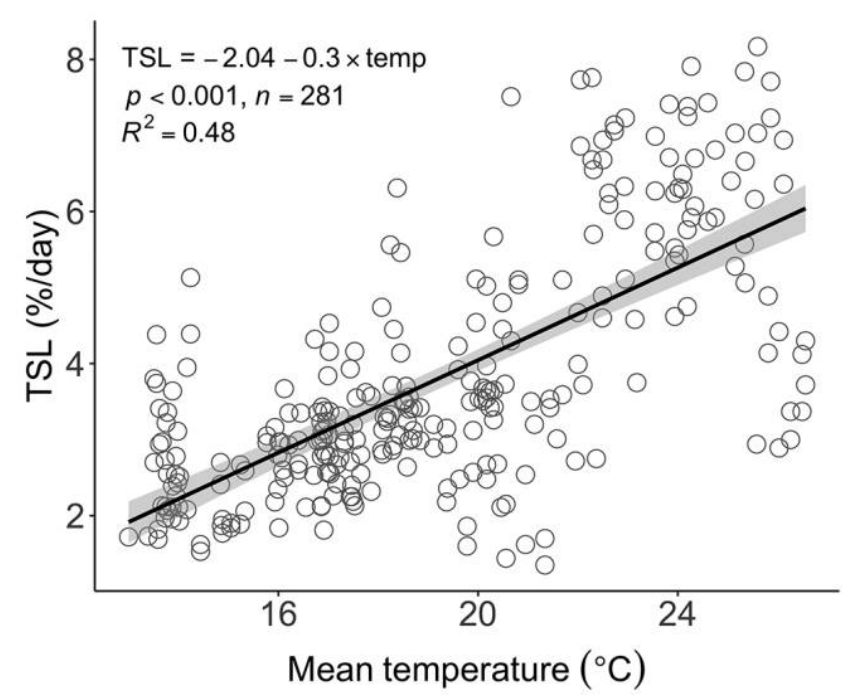

Figure 5. Linear relationship between non-adjusted tensilestrength loss rates (TSL, \%/d) and mean temperature in floc for all seasons and depths. Each point represents a single cotton strip. A line of best fit (solid black line) and 95\% confidence intervals (gray area) are overlain. 


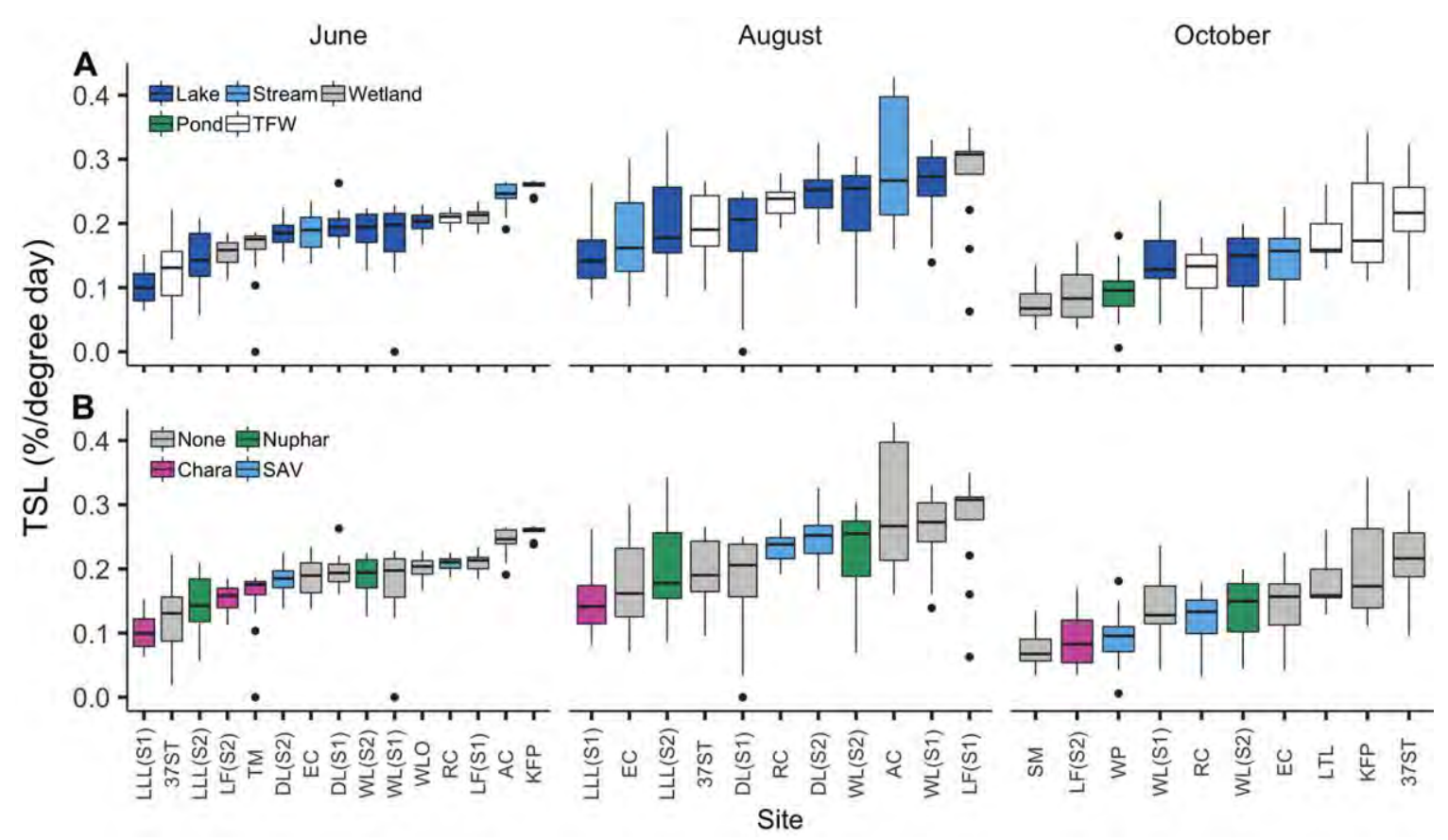

Figure 6. Temperature-adjusted tensile-strength loss (TSL) rates for all depths in the floc at each site, arranged in order of increasing median TSL rates for each season, and colored by waterbody type (A) and dominant vegetation type (B). Boxplots represent the median and interquartile range; outliers are depicted as black points. Site abbreviations: $37^{\text {th }}$ Street Marsh (37ST), Augusta Creek (AC), Douglas Lake (DL), Eagle Creek (EC), Kellogg Forest Pond (KFP), Little Long Lake (LLL), Loosestrife Fen (LF), Lower Three Lakes (LTL), Ransom Creek (RC), Sheriffs Marsh (SM), Turkey Marsh (TM), Windmill Pond (WP), Wintergreen Lake (WL), and Wintergreen Lake Outflow (WLO).

waterbodies (Kincaid 2018). Divalent cations (e.g., $\mathrm{Ca}^{2+}$ ) can prevent organic acids, such as polyphenols derived from plant litter, from complexing with and inactivating extracellular enzymes that degrade cellulose (Wetzel 1990, 1992). In this study, the mean $\mathrm{Ca}^{2+}$ concentration in overlying waters $(1305 \mu \mathrm{M})$ was $\sim^{1 / 2}$ the mean $\mathrm{Ca}^{2+}$ concentration of in floc porewaters $(2667 \mu \mathrm{M})$ and temperature-adjusted TSL ratios moved closer to unity as the $\mathrm{Ca}^{2+}$ concentrations in overlying water increased. This suggests that polyphenols may have suppressed enzyme activities, and consequently TSL rates, in overlying waters with low $\mathrm{Ca}^{2+}$ concentrations. The potential importance of these factors for decomposition rates in floc warrants further investigation.

\section{Predictors of decomposition in floc}

Temperature is a fundamental driver of many biological processes, including the metabolism of microorganisms (Yvon-Durocher et al. 2010). It was therefore unsurprising that temperature was a good predictor of TSL rates in floc. Non-adjusted TSL rates were positively correlated with mean floc temperature (Fig. 5), and mean rates in floc and overlying water followed patterns in seasonal water temperatures, with the greatest rates occurring in August, the warmest month in this study (Figs. 2A, 3A). The positive relationship between temperature and microbially-driven decomposition in aquatic ecosystems is well established
(Gudasz et al. 2010, Boyero et al. 2011, Follstad Shah et al. 2017), although seasonal variation in sediment degradation rates can also be influenced by other factors like seasonal changes in the sources and quality of organic $C$ inputs (Schulz 1995).

The most important predictor of temperature-adjusted TSL rates within floc was the concentration of SRP in porewaters, and TSL rates increased with increasing SRP concentrations (Appendix S1, Table S7). This could be the result of: 1) decomposition being limited by $\mathrm{P}, 2$ ) sites with greater decomposition increasing SRP availability through mineralization of organic C, 3) SRP co-varying with another predictor of decomposition that we did not measure, or 4) some combination of all of these factors. Studies that have manipulated $\mathrm{P}$ availability suggest that decomposition in sediments is P limited (Federle and Vestal 1980, Rüegg et al. 2011, Tiegs et al. 2013b, Vizza et al. 2017). For example, in the oligotrophic Florida Everglades, P enrichment increased cotton-strip decomposition rates in sediments (Newman et al. 2001) and enhanced respiration rates of incubated floc (Pisani et al. 2015). In a study conducted in the same region as this study, aquatic vascular plant litter decomposed faster in the littoral zone of a hypereutrophic lake enriched in SRP than in a similar habitat in a nearby lake with much lower SRP concentrations, despite relatively low oxygen availability in the hypereutrophic lake (Godshalk 

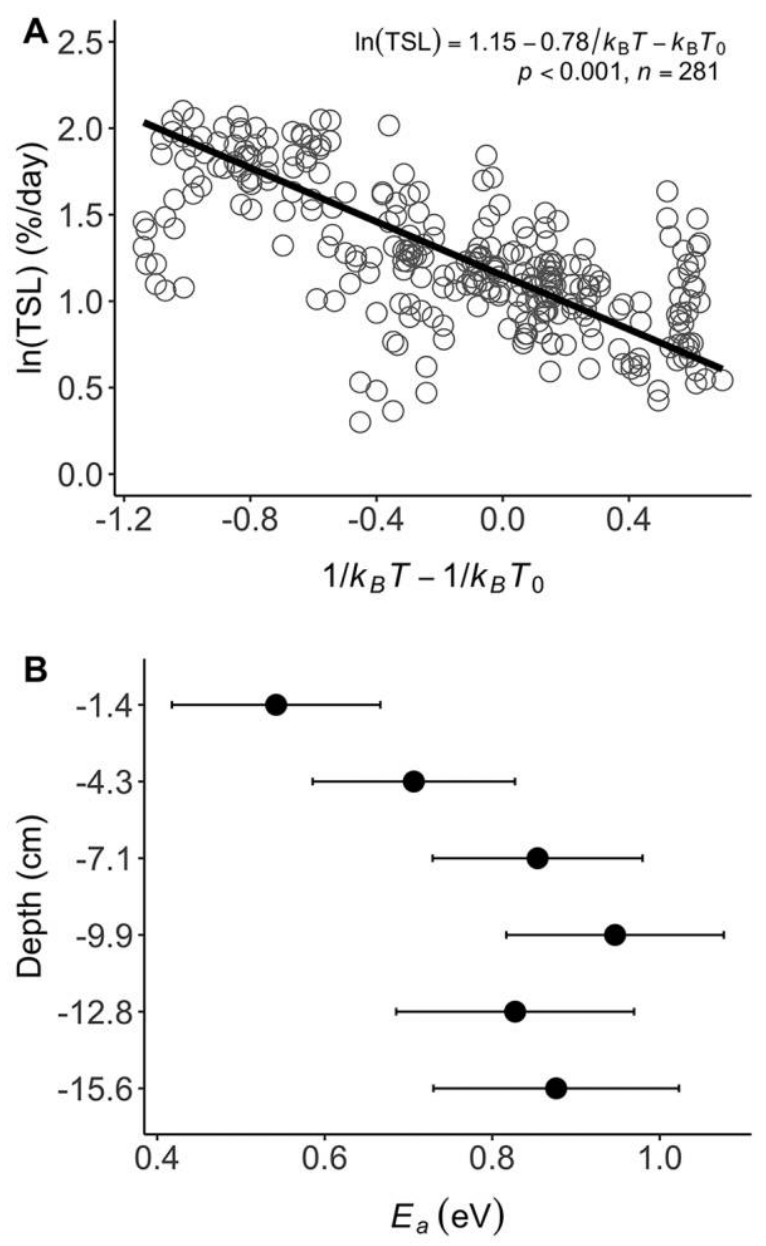

Figure 7. A.-The apparent activation energy $\left(E_{a}, \mathrm{eV}\right)$ of non-adjusted tensile-strength loss rates (TSL, \%/d) of cotton strips deployed in flocculent sediment. The $\mathrm{x}$-axis is the inverse absolute temperature $(T)$ in Kelvin (K) multiplied by the Boltzmann constant $\left(k_{B}, 8.62 \times 10^{-5} \mathrm{eV} / \mathrm{K}\right)$ and normalized by a standard water temperature $\left(T_{0}\right), 291.15 \mathrm{~K}$ or $18^{\circ} \mathrm{C}$. The slope approximates the inverse of $E_{a}$. Each point represents a single cotton strip. B.-The apparent activation energy of TSL at each depth in the floc. Bars represent the $95 \%$ confidence intervals.

and Wetzel 1978). These studies together provide evidence for P limitation of decomposition in freshwater sediments in nutrient-poor and -rich waterbodies.

$\mathrm{Fe}^{2+}$ concentrations only had $\sim^{1 / 2}$ the predictive power of SRP, but temperature-adjusted TSL rates tended to increase with increasing concentrations of $\mathrm{Fe}^{2+}$ in floc porewaters. The presence of $\mathrm{Fe}^{2+}$ in floc porewaters may be an indicator of 1 of 2 processes that contribute to enhanced decomposition rates. First, microbial reduction of ferric iron $\left(\mathrm{Fe}^{3+}\right)$ to $\mathrm{Fe}^{2+}$ is an important pathway in the anaerobic degradation of sediment organic matter, for example in freshwater lakes (Thamdrup 2000, Lovley et al. 2004, Lau et al. 2015) and Arctic peat soils (Lipson et al. 2010). Second, in sediments, $\mathrm{P}$ is often sorbed as the inorganic phosphate $\left(\mathrm{PO}_{4}{ }^{3-}\right)$ ion to inorganic metal oxides, particularly to poorly crystalline iron oxyhydroxides. In the absence of oxygen, $\mathrm{Fe}^{3+}$ is reduced to $\mathrm{Fe}^{2+}$ and Fe-bound P is released to sediment porewaters (Boström et al. 1988). Increased available $\mathrm{P}$, as explained earlier, could then enhance decomposition rates.

The negative relationship between temperature-adjusted TSL rates in floc and $\mathrm{NH}_{4}{ }^{+}$concentrations in floc porewaters may be another indicator that decomposition rates were P limited. In floc porewaters, $\mathrm{NH}_{4}{ }^{+}$comprised on average $99 \%$ of dissolved inorganic $\mathrm{N}\left(\mathrm{DIN} ; \mathrm{NO}_{3}{ }^{-}+\mathrm{NH}_{4}{ }^{+}\right)$. Floc porewaters at most sites had DIN to SRP ratios greater than the Redfield ratio, and as this ratio increased the temperature-adjusted TSL rates tended to decrease, although this trend was only significant $(p<0.05)$ for June and October when all depths were considered together (Fig. 8). Similarly, Vizza et al. (2017) found that decomposition rates of cotton strips in wetland ponds were negatively related to surface water $\mathrm{TN}$ : TP ratios. In these examples, the lower availability of $\mathrm{P}$ relative to $\mathrm{N}$ suggests that $\mathrm{P}$ availability would limit decomposition.

Ammonia inhibition could conceivably contribute to the negative relationship between temperature-adjusted TSL rates in floc and $\mathrm{NH}_{4}{ }^{+}$concentrations in floc porewaters. We cannot rule this mechanism out conclusively, but it is unlikely that ammonia toxicity resulted in reduced TSL rates because the maximum concentration of $\mathrm{NH}_{4}{ }^{+}$that we measured in floc porewaters $(\sim 1500 \mu \mathrm{M})$ was 2 to 3 orders of magnitude less than inhibitory concentrations reported in the literature (Chen et al. 2008). Similarly, when we assessed which floc porewater chemistry variables were the best predictors of temperature-adjusted TSL rates, the $\Sigma \mathrm{H}_{2} \mathrm{~S}$ concentration was a marginally-significant negative predictor ( $p=0.08$; Model M7 in Appendix S1, Table S7), but again, the maximum concentration of $\Sigma \mathrm{H}_{2} \mathrm{~S}$ that we measured in floc porewaters $(\sim 160 \mu \mathrm{M})$ was 1 to 2 orders of magnitude less than inhibitory concentrations reported in the literature (Chen et al. 2008). Therefore, ammonia and sulfide likely did not inhibit decomposition rates in floc.

\section{Apparent temperature sensitivity of decomposition in floc}

The overall apparent activation energy $\left(E_{a}\right)$ of decomposition rates in floc across all depths, sites, and seasons $(0.78 \pm$ $0.04 \mathrm{eV}$ ) is considerably greater than predicted for respiration in general and for short-term ecosystem respiration in aquatic systems in particular, which are both $\sim 0.6 \mathrm{eV}$ (Brown et al. 2004, Allen et al. 2005, Yvon-Durocher et al. 2012). Differences in the temperature dependence of decomposition can be driven by differences in organic-matter quality (Bosatta and Ågren 1999, Cornwell et al. 2008, Makkonen et al. 2012, Follstad Shah et al. 2017). However, Tiegs et al. (2019) found that the $E_{a}$ of TSL for cotton strips deployed in stream channels $(\sim 0.6 \mathrm{eV} ; n>500)$ was similar 


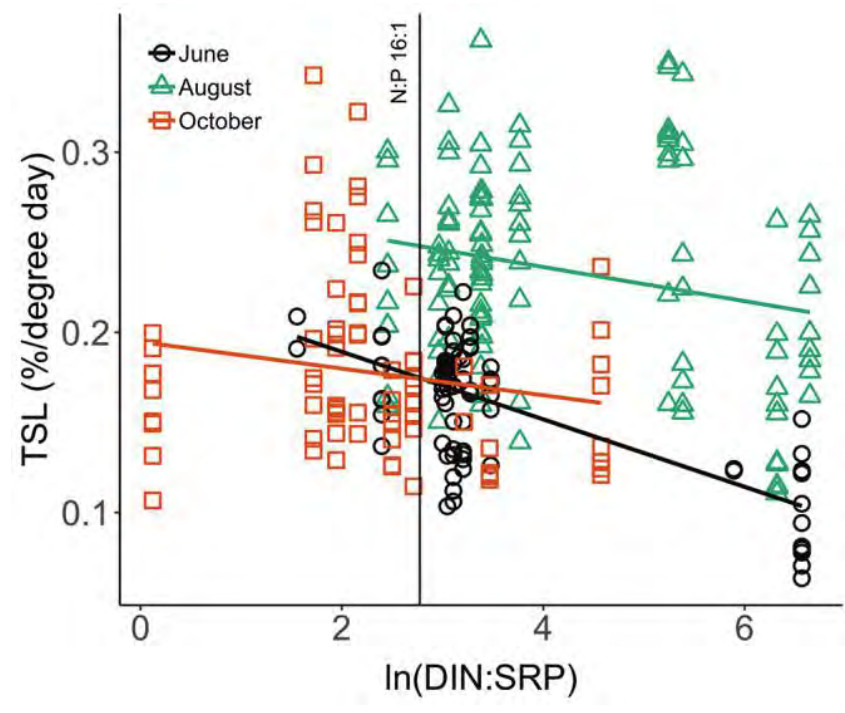

Figure 8. Linear relationships for each season between temperature-adjusted tensile-strength loss rates (TSL, \%/ degday) in floc and the natural log of the molar ratio of dissolved inorganic $\mathrm{N}$ (DIN: $\mathrm{NO}_{3}{ }^{-}+\mathrm{NH}_{4}{ }^{+}$) to SRP concentrations in the floc porewaters. The data are limited to cotton strips with TSL between 25 and 75\%. Each point represents a single cotton strip. Linear regressions were significant $(p<0.05)$ for June and October, but not for August. The vertical line shows the $16: 1$ molar $\mathrm{N}: \mathrm{P}$ ratio.

to the $E_{a}$ predicted for respiration of organic $C$ in soil and aquatic ecosystems. This similarity suggests that the greater $E_{a}$ for decomposition of cotton strips in floc is not driven by differences in organic matter quality, but rather by environmental differences.

We did not directly examine the environmental factors that contribute to a greater $E_{a}$ in this study, but we suggest they may result from shifts in microbial assemblages driven by gradients in oxygen availability and organic matter quality. The $E_{a}$ estimate in the upper centimeters of floc where oxygen may be present transiently was $\sim 0.6 \mathrm{eV}$ in this study (Fig. 7B). In deeper layers of floc, where oxygen is unavailable most of the time and anaerobic processes dominate, $E_{a}$ increased and reflected the $E_{a}$ for methane production in freshwater sediment incubations $(0.93 \mathrm{eV}$; Yvon-Durocher et al. 2014). Similarly, labile organic-matter inputs are likely less frequent in the deeper layers of floc and microbial assemblages may shift toward decomposers of more recalcitrant $C$, which requires a higher activity of extracellular enzymes (Ylla et al. 2012).

\section{Conclusions}

Our primary goal in this study was to investigate decomposition rates in flocculent organic sediment, and compare these to rates in other freshwater settings where the cottonstrip assay has been used. Contrary to our expectation, decomposition rates in floc sediments measured in this study were an average of $1.7 \times$ higher than rates measured in overlying waters and were only lower than temperatureadjusted rates reported in streams, which are generally flowing and well oxygenated. This result is similar to some studies, particularly those in marine sediments, that demonstrate that decomposition in anoxic environments is not always slower than in oxic environments (Kristensen et al. 1995, Hulthe et al. 1998, Kristensen and Holmer 2001). Further, our results show that the thick layers of floc in certain environments are not the result of slow decomposition rates.

Accumulation of organic floc can only occur when organic $C$ inputs exceed decomposition, so floc sediments may be sustained by particularly high rates of organic $C$ input. The environments in which we observed thick accumulations of floc often had obviously high autochthonous inputs from aquatic vascular plants, allochthonous inputs of terrigenous organic $\mathrm{C}$ deposited by advective flows from upstream, or both. Terrigenous $\mathrm{C}$ tends to have complex, aromatic structures and high $\mathrm{C}$ to nutrient ratios (McGroddy et al. 2004, Lau et al. 2008), so it is often resistant to microbial decomposition (Kleber et al. 2011, Attermeyer et al. 2014) and is more likely to accumulate. However, floc can often be found in shallow productive waters far from shorelines or advective inputs of terrigenous $\mathrm{C}$. Another possibility is that the flocculent nature of the particulate matter inhibits decomposition of the native organic matter in some way that is not exhibited with fixed cotton strips inserted into floc. The factors promoting the accumulation of floc are perplexing and warrant further investigation. Specifically, more information on inputs, transformations, and losses of organic $\mathrm{C}$ is needed.

This study also demonstrated how environmental variables within floc, specifically, porewater chemistry and temperature, affect decomposition rates. Decomposition in floc may be limited by the availability of $\mathrm{P}$ or the ratio of $\mathrm{N}$ to $\mathrm{P}$ available in the porewaters. Further, warmer temperatures led to increased decomposition rates, and the temperature sensitivity results suggest that rates of decomposition in floc could increase 11 to $52 \%$ with a 1 to $4^{\circ} \mathrm{C}$ increase in water temperatures, a range that is realistic for this region in the next $100 \mathrm{y}$ if climate change continues at the current pace (Winslow et al. 2015). If decomposition outpaces organic $\mathrm{C}$ inputs in a warmer world, stocks of sediment organic $\mathrm{C}$ in freshwaters may decline.

\section{ACKNOWLEDGEMENTS}

Author contributions: DWK, NAHL, and SKH conceived of the research ideas and design. DWK, NAHL, and SDT acquired the data. DWK and NAHL analyzed the data. DWK drafted the manuscript. NAHL, SDT, and SKH provided critical revisions of the manuscript.

This research was made possible through support from the NSF Long-term Ecological Research Program (DEB 1637653) at the Kellogg Biological Station and by Michigan State University AgBioResearch. Jay Zarnetske and Martin Briggs contributed to 
the conceptual development of this research. David Weed, Stuart Findlay, Heather Malcom, and Jezreel Wallace provided laboratory assistance, and Diana Ethaiya performed the tensile-strength measurements. Abdhi Sarkar and Michigan State University's Center for Statistical Training and Consulting provided valuable guidance with statistical analyses. We also wish to extend a special thanks to Gretchen Allison for preparing the hundreds of cotton strips used in this study as a volunteer.

\section{LITERATURE CITED}

Allen, A. P., J. F. Gillooly, and J. H. Brown. 2005. Linking the global carbon cycle to individual metabolism. Functional Ecology 19: 202-213.

Aller, R. C. 1994. Bioturbation and remineralization of sedimentary organic matter: Effects of redox oscillation. Chemical Geology 114:331-345

Aller, R. C., N. E. Blair, Q. Xia, and P. D. Rude. 1996. Remineralization rates, recycling, and storage of carbon in Amazon shelf sediments. Continental Shelf Research 16:753-786.

Aminot, A., D. S. Kirkwood, and R. Kérouel. 1997. Determination of ammonia in seawater by the indophenol-blue method: Evaluation of the ICES NUTS I/C 5 questionnaire. Marine Chemistry 56:59-75.

Attermeyer, K., T. Hornick, Z. E. Kayler, A. Bahr, E. Zwirnmann, H. P. Grossart, and K. Premke. 2014. Enhanced bacterial decomposition with increasing addition of autochthonous to allochthonous carbon without any effect on bacterial community composition. Biogeosciences 11:1479-1489.

Battin, T. J., S. Luyssaert, L. A. Kaplan, A. K. Aufdenkampe, A. Richter, and L. J. Tranvik. 2009. The boundless carbon cycle. Nature Geoscience 2:598-600.

Benjamini, Y., and Y. Hochberg. 1995. Controlling the false discovery rate: A practical and powerful approach to multiple testing. Journal of the Roval Statistical Society: Series B (Methodological) 57:289-300.

Benner, R., M. A. Moran, and R. E. Hodson. 1986. Biogeochemical cycling of lignocellulosic carbon in marine and freshwater ecosystems: Relative contributions of procaryotes and eucaryotes. Limnology and Oceanography 31:89-100.

Bosatta, E., and G. I. Ågren. 1999. Soil organic matter quality interpreted thermodynamically. Soil Biology and Biochemistry 31:1889-1891.

Boström, B., J. M. Andersen, S. Fleischer, and M. Jansson. 1988. Exchange of phosphorus across the sediment-water interface. Hydrobiologia 170:229-244.

Boyero, L., R. G. Pearson, M. O. Gessner, L. A. Barmuta, V. Ferreira, M. A. S. Graça, D. Dudgeon, A. J. Boulton, M. Callisto, E. Chauvet, J. E. Helson, A. Bruder, R. J. Albariño, C. M. Yule, M. Arunachalam, J. N. Davies, R. Figueroa, A. S. Flecker, A. Ramírez, R. G. Death, T. Iwata, J. M. Mathooko, C. Mathuriau, J. F. Gonçalves, M. S. Moretti, T. Jinggut, S. Lamothe, C. M'Erimba, L. Ratnarajah, M. H. Schindler, J. Castela, L. M. Buria, A. Cornejo, V. D. Villanueva, and D. C. West. 2011. A global experiment suggests climate warming will not accelerate litter decomposition in streams but might reduce carbon sequestration. Ecology Letters 14:289-294.

Brainard, A. S., and G. W. Fairchild. 2012. Sediment characteristics and accumulation rates in constructed ponds. $\underline{\text { Journal of }}$ Soil and Water Conservation 67:425-432.
Brown, J. H., J. F. Gillooly, A. P. Allen, V. M. Savage, and G. B. West. 2004. Toward a metabolic theory of ecology. Ecology 85:1771-1789.

Bruland, G. L., S. Grunwald, T. Z. Osborne, K. R. Reddy, and S. Newman. 2006. Spatial distribution of soil properties in Water Conservation Area 3 of the Everglades. Soil Science Societv of America Journal 70:1662-1676.

Burdige, D. J. 2007. Preservation of organic matter in marine sediments: Controls, mechanisms, and an imbalance in sediment organic carbon budgets? Chemical Reviews 107:467-485.

Chen, Y., J. J. Cheng, and K. S. Creamer. 2008. Inhibition of anaerobic digestion process: A review. Bioresource Technology 99:4044-4064.

Cole, J. J., Y. T. Prairie, N. F. Caraco, W. H. McDowell, L. J. Tranvik, R. G. Striegl, C. M. Duarte, P. Kortelainen, J. A. Downing, J. J. Middelburg, and J. Melack. 2007. Plumbing the global carbon cycle: Integrating inland waters into the terrestrial carbon budget. Ecosystems 10:172-185.

Cornwell, W. K., J. H. C. Cornelissen, K. Amatangelo, E. Dorrepaal, V. T. Eviner, O. Godoy, S. E. Hobbie, B. Hoorens, H. Kurokawa, N. Pérez-Harguindeguy, H. M. Quested, L. S. Santiago, D. A. Wardle, I. J. Wright, R. Aerts, S. D. Allison, P. van Bodegom, V. Brovkin, A. Chatain, T. V. Callaghan, S. Díaz, E. Garnier, D. E. Gurvich, E. Kazakou, J. A. Klein, J. Read, P. B. Reich, N. A. Soudzilovskaia, M. V. Vaieretti, and M. Westoby. 2008. Plant species traits are the predominant control on litter decomposition rates within biomes worldwide. Ecology Letters 11:1065-1071.

Costello, D. M., and G. A. Burton. 2014. Response of stream ecosystem function and structure to sediment metal: Contextdependency and variation among endpoints. Elementa: Science of the Anthropocene 2.

de Boer, W., L. B. Folman, R. C. Summerbell, and L. Boddy. 2005. Living in a fungal world: Impact of fungi on soil bacterial niche development. FEMS Microbiology Reviews 29:795-811.

DeBusk, W. F., and K. R. Reddy. 1998. Turnover of detrital organic carbon in a nutrient-impacted Everglades marsh. Soil Science Society of America Journal. 62:1460-1468.

Downing, J. 2010. Emerging global role of small lakes and ponds: Little things mean a lot. Limnetica 29:9-24.

Downing, J. A., J. J. Cole, J. J. Middelburg, R. G. Striegl, C. M. Duarte, P. Kortelainen, Y. T. Prairie, and K. A. Laube. 2008. Sediment organic carbon burial in agriculturally eutrophic impoundments over the last century. Global Biogeochemical Cycles 22.

Federle, T. W., and J. R. Vestal. 1980. Lignocellulose mineralization by Arctic lake sediments in response to nutrient manipulation. Applied and Environmental Microbiology 40:32-39.

Fenchel, T., G. King, and T. H. Blackburn. 2012. Bacterial biogeochemistry: The ecophysiology of mineral cycling. $3^{\text {rd }}$ edition. Academic Press, London, United Kingdom.

Ferland, M.-E., P. A. del Giorgio, C. R. Teodoru, and Y. T. Prairie. 2012. Long-term $C$ accumulation and total $C$ stocks in boreal lakes in northern Québec. Global Biogeochemical Cycles 26.

Ferland, M.-E., Y. T. Prairie, C. Teodoru, and P. A. del Giorgio. 2014. Linking organic carbon sedimentation, burial efficiency, and long-term accumulation in boreal lakes. Journal of Geophysical Research: Biogeosciences 119:836-847. 
Flanagan, K. M., and E. McCauley. 2010. Experimental warming increases $\mathrm{CO}_{2}$ saturation in a shallow prairie pond. Aquatic Ecology 44:749-759.

Follstad Shah, J. J., J. S. Kominoski, M. Ardón, W. K. Dodds, M. O. Gessner, N. A. Griffiths, C. P. Hawkins, S. L. Johnson, A. Lecerf, C. J. LeRoy, D. W. P. Manning, A. D. Rosemond, R. L. Sinsabaugh, C. M. Swan, J. R. Webster, and L. H. Zeglin. 2017. Global synthesis of the temperature sensitivity of leaf litter breakdown in streams and rivers. Global Change Biology 19: 202-12.

Gessner, M. O., and S. Y. Newell. 2002. Biomass, growth rate, and production of filamentous fungi in plant litter. Pages 390-408 in C. J. Hurst, R. L. Crawford, G. R. Knudsen, M. J. McInerney, and L. D. Stetzenbach (editors). Manual of Environmental Microbiology. American Society for Microbiology Press, Washington, DC.

Glud, R. N. 2008. Oxygen dynamics of marine sediments. Marine Biology Research 4:243-289.

Godshalk, G. L., and R. G. Wetzel. 1978. Decomposition of aquatic angiosperms. II. Particulate components. Aquatic Botany 5:301327.

Golterman, H. L., and R. S. Clymo. 1969. Methods for chemical analysis of fresh waters. Blackwell Scientific Publications, Oxford, United Kingdom.

Griffiths, N. A., and S. D. Tiegs. 2016. Organic-matter decomposition along a temperature gradient in a forested headwater stream. Freshwater Science 35:518-533.

Gudasz, C., D. Bastviken, K. Steger, K. Premke, S. Sobek, and L. J. Tranvik. 2010.Temperature-controlled organic carbon mineralization in lake sediments. Nature 466:478-481.

Gudasz, C., S. Sobek, D. Bastviken, B. Koehler, and L. J. Tranvik. 2015. Temperature sensitivity of organic carbon mineralization in contrasting lake sediments. Iournal of Geophysical Research: Biogeosciences 120:1215-1225.

Gulis, V., and K. F. Suberkropp. 2006. Fungi: Biomass, production, and sporulation of aquatic hyphomycetes. Pages 311325 in F. R. Hauer and G. A. Lamberti (editors). Methods in Stream Ecology. Elsevier, Amsterdam, The Netherlands.

Güsewell, S., and M. O. Gessner. 2009. N : P ratios influence litter decomposition and colonization by fungi and bacteria in microcosms. Functional Ecology 23:211-219.

Harrison, A. F., P. M. Latter, and D. W. H. Whalton. 1988. Cotton strip assay: An index of decomposition in soil. Institute of Terrestrial Ecology, Merlewood Research Station, Cumbria, United Kingdom.

Hervé, P., S. D. Tiegs, S. Grellier, K. M. Wantzen, and F. IsselinNondedeu. 2019. Combined effects of vegetation and drought on organic-matter decomposition in vernal pool soils. Wetlands 39:321-327.

Hill, M. O., P. M. Latter, and G. Bancroft. 1985. A standard curve for inter-site comparison of cellulose degradation using the cotton strip method. Canadian Journal of Soil Science 65: 609-619.

Hulthe, G., S. Hulth, and P. O. J. Hall. 1998. Effect of oxygen on degradation rate of refractory and labile organic matter in continental margin sediments. Geochimica et Cosmochimica Acta 62:1319-1328.

Imberger, S. J., R. M. Thompson, and M. R. Grace. 2010. Searching for effective indicators of ecosystem function in urban streams: Assessing cellulose decomposition potential. Freshwater Biology 55:2089-2106.

Inglett, P. W., V. H. Rivera-Monroy, and J. R. Wozniak. 2011. Biogeochemistry of nitrogen across the Everglades landscape. Critical Reviews in Environmental Science and Technology 41:187-216.

Kieber, R. J., R. F. Whitehead, and S. A. Skrabal. 2006. Photochemical production of dissolved organic carbon from resuspended sediments. Limnology and Oceanography 51:21872195.

Kincaid, D. W. 2018. Revealing the biogeochemistry and hydrodynamic exchange processes of flocculent sediments in shallow freshwaters. PhD Thesis. Michigan State University, East Lansing, Michigan.

Kinsman-Costello, L. E., J. M. O’Brien, and S. K. Hamilton. 2015. Natural stressors in uncontaminated sediments of shallow freshwaters: The prevalence of sulfide, ammonia, and reduced iron. Environmental Toxicology and Chemistry 34:467-479.

Kleber, M., P. S. Nico, A. Plante, T. Filley, M. Kramer, C. Swanston, and P. Sollins. 2011. Old and stable soil organic matter is not necessarily chemically recalcitrant: Implications for modeling concepts and temperature sensitivity. Global Change Biology 17:1097-1107.

Komínková, D., K. A. Kuehn, N. Büsing, D. Steiner, and M. O. Gessner. 2000. Microbial biomass, growth, and respiration associated with submerged litter of Phragmites australis decomposing in a littoral reed stand of a large lake. Aquatic Microbial Ecology 22:271-282.

Kortelainen, P., H. Pajunen, M. Rantakari, and M. Saarnisto. 2004. A large carbon pool and small sink in boreal Holocene lake sediments. Global Change Biology 10:1648-1653.

Kristensen, E., S. I. Ahmed, and A. H. Devol. 1995. Aerobic and anaerobic decomposition of organic matter in marine sediment: Which is fastest? Limnology and Oceanography 40: 1430-1437.

Kristensen, E., and M. Holmer. 2001. Decomposition of plant materials in marine sediment exposed to different electron acceptors $\left(\mathrm{O}_{2}, \mathrm{NO}_{3}{ }^{-}\right.$, and $\left.\mathrm{SO}_{4}{ }^{2-}\right)$, with emphasis on substrate origin, degradation kinetics, and the role of bioturbation. Geochimica et Cosmochimica Acta 65:419-433.

Kuehn, K. A. 2016. Lentic and lotic habitats as templets for fungal communities: Traits, adaptations, and their significance to litter decomposition within freshwater ecosystems. Fungal Ecology 19:135-154.

Kuehn, K. A., S. N. Francoeur, R. H. Findlay, and R. K. Neely. 2014. Priming in the microbial landscape: Periphytic algal stimulation of litter-associated microbial decomposers. Ecology 95:749-762.

Kuehn, K. A., M. J. Lemke, K. Suberkropp, and R. G. Wetzel. 2000. Microbial biomass and production associated with decaying leaf litter of the emergent macrophyte Juncus effusus. Limnology and Oceanography 45:862-870.

Lau, D. C. P., K. M. Y. Leung, and D. Dudgeon. 2008. Experimental dietary manipulations for determining the relative importance of allochthonous and autochthonous food resources in tropical streams. Freshwater Biology 53:139-147.

Lau, M. P., M. Sander, J. Gelbrecht, and M. Hupfer. 2015. Solid phases as important electron acceptors in freshwater organic sediments. Biogeochemistry 123:49-61. 
Leschine, S. B. 1995. Cellulose degradation in anaerobic environments. Annual Review of Microbiology 49:399-426.

Lipson, D. A., M. Jha, T. K. Raab, and W. C. Oechel. 2010. Reduction of iron (III) and humic substances plays a major role in anaerobic respiration in an Arctic peat soil. Journal of Geophysical Research 115.

Longhi, D., M. Bartoli, D. Nizzoli, and P. Viaroli. 2013. Benthic processes in fresh water fluffy sediments undergoing resuspension. Journal of Limnology 72:1-12.

Lovley, D. R., D. E. Holmes, and K. P. Nevin. 2004. Dissimilatory $\mathrm{Fe}(\mathrm{III})$ and $\mathrm{Mn}(\mathrm{IV})$ reduction. Advances in Microbial Physiology 49:219-286.

Lovley, D. R., and E. J. P. Phillips. 1987. Rapid assay for microbially reducible ferric iron in aquatic sediments. Applied and Environmental Microbiology 53:1536-1540.

Lynd, L. R., P. J. Weimer, W. H. van Zyl, and I. S. Pretorius. 2002. Microbial cellulose utilization: Fundamentals and biotechnology. Microbiology and Molecular Biology Reviews 66:506577.

Makkonen, M., M. P. Berg, I. T. Handa, S. Hättenschwiler, J. van Ruijven, P. M. van Bodegom, and R. Aerts. 2012. Highly consistent effects of plant litter identity and functional traits on decomposition across a latitudinal gradient. Ecology Letters 15:1033-1041.

Mayer, L. M., L. L. Schick, K. R. Hardy, and M. L. Estapa. 2009. Photodissolution and other photochemical changes upon irradiation of algal detritus. Limnology and Oceanography 54: 1688-1698.

Mayer, L. M., L. L. Schick, K. Skorko, and E. Boss. 2006. Photodissolution of particulate organic matter from sediments. Limnologv and Oceanography 51:1064-1071.

McGroddy, M. E., T. Daufresne, and L. O. Hedin. 2004. Scaling of $\mathrm{C}: \mathrm{N}: \mathrm{P}$ stoichiometry in forests worldwide: Implications of terrestrial Redfield-type ratios. Ecology 85:2390-2401.

Megonigal, J. P., M. E. Hines, and P. T. Visscher. 2004. Anaerobic metabolism: Linkages to trace gases and aerobic processes. Biogeochemistry.

Murphy, J., and J. P. Riley. 1962. A modified single solution method for the determination of phosphate in natural waters. Analytica Chimica Acta 27:31-36.

NADP, and NTN (National Atmospheric Deposition Program, and National Trends Network). 2011. National Atmospheric Deposition Program (NRSP-3)/National Trends Network means of annual volume-weighted means for 1979- 2010 from the KBS station (MI26). Illinois State Water Survey, Champaign, Illinois.

Newell, S. Y. 1992. Estimating fungal biomass and productivity in decomposing litter. Pages 521-561 in G. C. Carroll and D. T. Wicklow (editors). The Fungal Community: Its organization and role in the ecosystem. Marcel Dekker, New York, New York.

Newman, S., H. Kumpf, J. A. Laing, and W. C. Kennedy. 2001. Decomposition responses to phosphorus enrichment in an Everglades (USA) slough. Biogeochemistry 54:229-250.

Noe, G. B., L. J. Scinto, J. Taylor, D. L. Childers, and R. D. Jones. 2003. Phosphorus cycling and partitioning in an oligotrophic Everglades wetland ecosystem: A radioisotope tracing study. Freshwater Biology 48:1993-2008.

Pérez, J., J. Muñoz-Dorado, T. de la Rubia, and J. Martínez. 2002. Biodegradation and biological treatments of cellulose, hemi- cellulose and lignin: An overview. International Microbiology 5:53-63.

Pinheiro, J., D. Bates, S. DebRoy, D. Sarkar, and R. C. Team. 2017. nlme: Linear and Nonlinear mixed effects models.

Pisani, O., L. J. Scinto, J. W. Munyon, and R. Jaffé. 2015. The respiration of flocculent detrital organic matter (floc) is driven by phosphorus limitation and substrate quality in a subtropical wetland. Geoderma 241-242:272-278.

Pisani, O., Y. Yamashita, and R. Jaffé. 2011. Photo-dissolution of flocculent, detrital material in aquatic environments: Contributions to the dissolved organic matter pool. Water Research 45:3836-3844.

Reddy, K. R., S. Newman, T. Z. Osborne, J. R. White, and H. C. Fitz. 2011. Phosphorous cycling in the Greater Everglades Ecosystem: Legacy phosphorous implications for management and restoration. Critical Reviews in Environmental Science and Technology 41:149-186.

Reddy, K. R., and W. H. Patrick. 1975. Effect of alternate aerobic and anaerobic conditions on redox potential, organic matter decomposition and nitrogen loss in a flooded soil. Soil Biology and Biochemistry 7:87-94.

Revsbech, N. P., J. Nielsen, and P. K. Hansen. 1988. Benthic primary production and oxygen profiles. Pages 69-83 in T. H. Blackburn and J. Sørensen (editors). Nitrogen cycling in coastal marine environments. Wiley, Hoboken, New Jersey.

Rier, S. T., J. M. Shirvinski, and K. C. Kinek. 2014. In situ light and phosphorus manipulations reveal potential role of biofilm algae in enhancing enzyme-mediated decomposition of organic matter in streams. Freshwater Biology 59:1039-1051.

Rivero, R. G., S. Grunwald, T. Z. Osborne, K. R. Reddy, and S. Newman. 2007. Characterization of the spatial distribution of soil properties in Water Conservation Area 2A, Everglades, Florida. Soil Science 172:149-166.

Rüegg, J., S. D. Tiegs, D. T. Chaloner, P. S. Levi, J. L. Tank, and G. A. Lamberti. 2011. Salmon subsidies alleviate nutrient limitation of benthic biofilms in southeast Alaska streams. Canadian Journal of Fisheries and Aquatic Sciences 68:277-287.

Schulz, S. 1995. Effect of algal deposition on acetate and methane concentrations in the profundal sediment of a deep lake (Lake Constance). FEMS Microbiology Ecology 16:251-259.

Shank, G. C., A. Evans, Y. Yamashita, and R. Jaffé. 2011. Solar radiation-enhanced dissolution of particulate organic matter from coastal marine sediments. Limnology and Oceanography 56:577-588.

Sinsabaugh, R. L., M. M. Carreiro, and S. Alvarez. 2002. Enzyme and microbial dynamics of litter decomposition. Pages 249265 in R. G. Burns and R. P. Dick (editors). Enzymes in the Environment: Activity, Ecology, and Applications. Marcel Dekker, New York, New York.

Sobek, S., E. Durisch-Kaiser, R. Zurbrügg, N. Wongfun, M. Wessels, N. Pasche, and B. Wehrli. 2009. Organic carbon burial efficiency in lake sediments controlled by oxygen exposure time and sediment source. Limnology and Oceanography 54: 2243-2254.

Sobek, S., R. Zurbrügg, and I. Ostrovsky. 2011. The burial efficiency of organic carbon in the sediments of Lake Kinneret. Aquatic Sciences 73:355-364.

Sommer, B. 2006. Drying and re-wetting of organic wetland sediments: Biogeochemistry and implications for wetland 
management. PhD Thesis. Edith Cowan University, Perth, Australia.

Song, N., Z.-S. Yan, H.-Y. Cai, and H.-L. Jiang. 2013. Effect of temperature on submerged macrophyte litter decomposition within sediments from a large shallow and subtropical freshwater lake. Hydrobiologia 714:131-144.

Stookey, L. L. 1970. Ferrozine: A new spectrophotometric reagent for iron. Analytical Chemistry 42:779-781.

Sweerts, J. P., J. Rudd, and C. A. Kelly. 1986. Metabolic activities in flocculent surface sediments and underlying sandy littoral sediments. Limnology and Oceanography 31:330-338.

Tanaka, Y. 1991. Microbial decomposition of reed (Phragmites communis) leaves in a saline lake. Hydrobiologia 220:119-129.

Thamdrup, B. 2000. Bacterial manganese and iron reduction in aquatic sediments. Pages 41-84 in B. Schink (editor). Advances in Microbial Ecology. Springer, Boston, Massachusetts.

Thobaben, E. T., and S. K. Hamilton. 2014. The relative importance of groundwater and its ecological implications in diverse glacial wetlands. The American Midland Naturalist 172:205218.

Tiegs, S. D., J. E. Clapcott, N. A. Griffiths, and A. J. Boulton. 2013a. A standardized cotton-strip assay for measuring organicmatter decomposition in streams. Ecological Indicators 32: 131-139.

Tiegs, S. D., D. M. Costello, M. W. Isken, G. Woodward, P. B. McIntyre, M. O. Gessner, E. Chauvet, N. A. Griffiths, A. S. Flecker, V. Acuna, R. Albarino, D. C. Allen, C. Alonso, P. Andino, C. Arango, J. Aroviita, M. V. M. Barbosa, L. A. Barmuta, C. V. Baxter, T. D. C. Bell, B. Bellinger, L. Boyero, L. E. Brown, A. Bruder, D. A. Bruesewitz, F. J. Burdon, M. Callisto, C. Canhoto, K. A. Capps, M. M. Castillo, J. Clapcott, F. Colas, C. Colon-Gaud, J. Cornut, V. Crespo-Perez, W. F. Cross, J. M. Culp, M. Danger, O. Dangles, E. de Eyto, A. M. Derry, V. D. Villanueva, M. M. Douglas, A. Elosegi, A. C. Encalada, S. Entrekin, R. Espinosa, D. Ethaiya, V. Ferreira, C. Ferriol, K. M. Flanagan, T. Fleituch, J. J. Follstad Shah, A. Frainer Barbosa, N. Friberg, P. C. Frost, E. A. Garcia, L. García Lago, P. E. García Soto, S. Ghate, D. P. Giling, A. Gilmer, J. F. Goncalves, R. K. Gonzales, M. A. S. Graca, M. Grace, H.-P. Grossart, F. Guerold, V. Gulis, L. U. Hepp, S. Higgins, T. Hishi, J. Huddart, J. Hudson, S. Imberger, C. Iniguez-Armijos, T. Iwata, D. J. Janetski, E. Jennings, A. E. Kirkwood, A. A. Koning, S. Kosten, K. A. Kuehn, H. Laudon, P. R. Leavitt, A. L. Lemes da Silva, S. J. Leroux, C. J. LeRoy, P. J. Lisi, R. MacKenzie, A. M. Marcarelli, F. O. Masese, B. G. McKie, A. Oliveira Medeiros, K. Meissner, M. Milisa, S. Mishra, Y. Miyake, A. Moerke, S. Mombrikotb, R. Mooney, T. Moulton, T. Muotka, J. N. Negishi, V. Neres-Lima, M. L. Nieminen, J. Nimptsch, J. Ondruch, R. Paavola, I. Pardo, C. J. Patrick, E. T. H. M. Peeters, J. Pozo, C. Pringle, A. Prussian, E. Quenta, A. Quesada, B. Reid, J. S. Richardson, A. Rigosi, J. Rincón, G. Rîşnoveanu, C. T. Robinson, L. Rodríguez-Gallego, T. V. Royer, J. A. Rusak, A. C. Santamans, G. B. Selmeczy, G. Simiyu, A. Skuja, J. Smykla, K. R. Sridhar, R. Sponseller, A. Stoler, C. M. Swan, D. Szlag, F. Teixeira-de Mello, J. D. Tonkin, S. Uusheimo, A. M. Veach, S. Vilbaste, L. B. M. Vought, C.-P. Wang, J. R. Webster, P. B. Wilson, S. Woelfl, M. A. Xenopoulos, A. G. Yates, C. Yoshimura, C. M. Yule, Y. X. Zhang, and J. A. Zwart. 2019. Global patterns and drivers of ecosystem functioning in rivers and riparian zones. Science Advances 5: eaav0486.

Tiegs, S. D., S. A. Entrekin, G. H. Reeves, D. Kuntzsch, and R. W. Merritt. 2013b. Litter decomposition, and associated invertebrate communities, in wetland ponds of the Copper River Delta, Alaska (USA). Wetlands 33:1151-1163.

Tranvik, L. J., J. A. Downing, J. B. Cotner, S. A. Loiselle, R. G. Striegl, T. J. Ballatore, P. Dillon, K. Finlay, K. Fortino, and L. B. Knoll. 2009. Lakes and reservoirs as regulators of carbon cycling and climate. Limnology and Oceanography 54:22982314.

Vizza, C., J. A. Zwart, S. E. Jones, S. D. Tiegs, and G. A. Lamberti. 2017. Landscape patterns shape wetland pond ecosystem function from glacial headwaters to ocean. Limnology and Oceanography 10:7-15.

Wensink, S. M., and S. D. Tiegs. 2016. Shoreline hardening alters freshwater shoreline ecosystems. Freshwater Science 35:764777.

Wetzel, R. G. 1990. Land-water interfaces: Metabolic and limnological regulators. Internationale Vereinigung fuer Theoretische und Angewandte Limnologie 24:6-24.

Wetzel, R. G. 1992. Gradient-dominated ecosystems: Sources and regulatory functions of dissolved organic matter in freshwater ecosystems. Hydrobiologia 229:181-198.

Wetzel, R. G. 2001. Limnology: Lake and river ecosystems. $3^{\text {rd }}$ edition. Academic Press, San Diego, California.

Winslow, L. A., J. S. Read, G. J. A. Hansen, and P. C. Hanson. 2015. Small lakes show muted climate change signal in deepwater temperatures. Geophysical Research Letters 42:355-361.

Woodward, G., M. O. Gessner, P. S. Giller, V. Gulis, S. Hladyz, A. Lecerf, B. Malmqvist, B. G. McKie, S. D. Tiegs, H. Cariss, M. Dobson, A. Elosegi, V. Ferreira, M. A. S. Graca, T. Fleituch, J. O. Lacoursiere, M. Nistorescu, J. Pozo, G. Risnoveanu, M. Schindler, A. Vadineanu, L. B. M. Vought, and E. Chauvet. 2012. Continental-scale effects of nutrient pollution on stream ecosystem functioning. Science 336:1438-1440.

Wurzbacher, C. M., F. Bärlocher, and H. P. Grossart. 2010. Fungi in lake ecosystems. Aquatic Microbial Ecology 59:125-149.

Ylla, I., A. M. Romaní, and S. Sabater. 2012. Labile and recalcitrant organic matter utilization by river biofilm under increasing water temperature. Microbial Ecology 64:593-604.

Yvon-Durocher, G., A. P. Allen, D. Bastviken, R. Conrad, C. Gudasz, A. St-Pierre, N. Thanh-Duc, and P. A. del Giorgio. 2014. Methane fluxes show consistent temperature dependence across microbial to ecosystem scales. Nature 507:488-491.

Yvon-Durocher, G., J. M. Caffrey, A. Cescatti, M. Dossena, P. del Giorgio, J. M. Gasol, J. M. Montoya, J. Pumpanen, P. A. Staehr, M. Trimmer, G. Woodward, and A. P. Allen. 2012. Reconciling the temperature dependence of respiration across timescales and ecosystem types. Nature 487:472-476.

Yvon-Durocher, G., J. I. Jones, M. Trimmer, G. Woodward, and J. M. Montoya. 2010. Warming alters the metabolic balance of ecosystems. Philosophical Transactions of the Roval Society B: Biological Sciences 365:2117-2126.

Zuur, A. F., E. N. Ieno, N. Walker, A. A. Saveliev, and G. M. Smith. 2009. Mixed effects modelling for nested data. Pages 101-142 in Mixed effects models and extensions in ecology with $\mathrm{R}$. Springer, New York, New York. 